\title{
A scoping review of the nature of physiotherapists' role to avoid fall in people with Parkinsonism
}

\author{
Salem F. Alatawi ${ }^{1}$ (D) \\ Received: 21 July 2019 / Accepted: 18 December 2020 / Published online: 14 January 2021 \\ (C) The Author(s) 2020
}

\begin{abstract}
Background Parkinson's disease (PD) is considered a neurological disease with a high prevalence rate among population. One of its main problems is recurrent fall which has numerous contributing factors such as history of fall, fear of falling, gait deficits, impaired balance, poor functional mobility, and muscle weakness.

Objective To review and explore the focus/nature of interventions which target the role of physiotherapy preventing fall in patients with PD.

Method A scoping review was led dependent on Arksey and O'Malley as discussed by Wood et al. (2002). This paper based on this structure to perceive intervention studies have been embraced in physiotherapy to prevent fall after Parkinson's disease. The search included various databases. The referencing arrangements of every pertinent paper were additionally filtered for more studies.

Findings A total of 173 articles were included, 39 of which met the eligibility criteria. Fifteen studies reported on the direct impact of physiotherapy on fall, while the rest examined the impacts of physiotherapy on factors that are associated with fall. Different outcomes, interventions types, and duration were used in these studies. Findings showed a favorable result of physiotherapy on fall and near fall incidence, balance, gait, functional mobility, muscle strength, and fear of falling.

Conclusion Physiotherapy has the possibility to decrease fall incidence and fall risk in people with PD. However, the heterogeneity in the patients' selection, intervention studies, outcome measures chosen, time since the onset of disease, variation in intensity, and duration of treatment between included studies make the comparisons difficult. Consequently, more studies are needed on best intervention.
\end{abstract}

Keywords Parkinson's disease $\cdot$ Physiotherapy $\cdot$ Rehabilitation $\cdot$ Exercise $\cdot$ Falls $\cdot$ Risk factors

\section{Background}

Parkinson's disease (PD) is a common, exhausting, and progressive neurodegenerative disease. The elderly suffers from falls as part of the aging process, and PD patients have this as one of its complications [1].

Studies regarding the issue of falling found that those who are suffering from PD are more prone to falls compared either with healthy people of the same age or with the elderly who have other neurological conditions [2, 3]. A study by Bloem

Salem F. Alatawi

sfalatawi@ut.edu.sa

1 Associate professor of neurorehabilitation Department of Physical Therapy Faculty of Applied Medical Sciences, University of Tabuk, Tabuk City, Saudi Arabia et al. [2] conducted on fall prospectively in people with PD and in elderly people with good health found that PD results in a 9-fold increase in the likelihood of experiencing recurrent falls compared with healthy people of the same age. In Stolze et al.'s study (2004) [3], in comparison to patients with neurological disease "like stroke," the Parkinson's patients have two times risk of fall.

The incidence rate of falls through the Parkinson's patients ranged between 38 and $87 \%$ [4, 5]. In a study done by Hely et al. [6], measuring the risk of fall during 20 years of the Parkinson disease, $87 \%$ of them will experience falling at least one time. It was additionally discovered that falls in PD are intermittent. Pickering et al. [7] found that roughly $15 \%$ of individuals with this disease involvement have at least one fall each week, while different investigations announced that half of those with PD fell twice or more throughout 1 year. In this manner, a high number will experience the complications of falling. 
Recognizing the fall risk factors is of vital importance in fall prevention. As of late, a lot of research has been directed into the reasons for falls, and a substantial number of variables have been found.

A systematic review and meta-analysis tried to summarize the evidence regarding fall risk factors in people with PD [7]. However, the authors of this meta-analysis reviewed only six fall studies and found that the most solid factor which could anticipate future falls is a history of fall. However, in spite of the fact that this factor supports the belief that fall in PD is intermittent and individuals with a previous history of fall are at extraordinary hazard and should be dealt with, this factor is not treatable in that knowing the history of fall leads to more falling can help people with PD to take preventative measures and does not show the reason for the first event of fall. Therefore, concentrating on other treatable elements related with fall is of incredible significance in the avoidance of the main fall, and should in this way be viewed as while assessing the impacts of any intervention or when designing an intervention to prevent fall. Studies exploring the reasons for fall have found different factors strongly related with falls and have recommended rehabilitation programs to focus on these components to prevent fall in individuals with PD. The most important factors include reduced balance, impaired gait, muscle weakness, poor functional mobility, or performance on functional tasks, and, in addition to these physical limitations, psychological factors are also found to be risk factors [4].

Physiotherapy is one of the most important approaches of treatment for people with PD. It has continually been observed to be a viable method to alter factors, for example, balance and gait, as to diminish the quantity of falls among the elderly [5].

Various reviews [5, 8-10] have been done to condense the proof and to decide if physiotherapy interventions are useful for individuals with PD. However, most of these reviews did not concentrate on falls, but instead, they researched the general potential advantages of physiotherapy intervention on individuals with PD to the extent that only one systematic review focused on fall. In this specific review, Allen et al. [10] searched the literature up to 2009 and directed a meta-analysis to decide the impacts of physiotherapy on balance and fall rates. The pooled estimate of the impact of physiotherapy in this review demonstrated a significant enhancement in balance. However, the authors did not discover adequate proof to help or discredit the impacts of physiotherapy intervention on diminishing fall rate. In another review, Shen et al. [11] examined the effects of exercise training on balance, gait ability, and falls against no intervention and placebo intervention. The authors concluded that there was no evidence that training decreased the number of fallers over the short or long term $(p$ $>0.05)$.

Regardless of the deficient proof given by aforementioned research, proof has risen out of a different review that has concentrated on the potential advantages of physiotherapy for individuals with PD, and a few advantages regarding balance and other fall-related variables have been accounted for. For instance, Kwakkel et al. and Goodwin et al. [12, 13] found that the utilization of physiotherapy gave promising outcomes, being valuable regarding balance, gait velocity, and muscle strength. In any case, the poor methodological nature of the studies incorporated into these reviews demonstrations to restrain both these reviews and the developed proof. In this manner, leading a review that centers around fall and incorporates just randomized controlled studies to decide if physiotherapy is gainful for fall chance decrease in individuals with $\mathrm{PD}$ is considered poor.

A systematic review is increasingly confined in center and tries to answer specific research inquiries from the available literature. However, the scoping review is a procedure intended to deliberately recognize the expansiveness of writing in a region being researched [1]. The intention of this paper was to scope the physiotherapy practice/role to prevent fall in patients with PD.

\section{Methods}

A scoping review was conducted including determining the research question; determining relevant studies and study selection; charting the data; and finally collating, summarizing, and reporting the findings. The main phase of searching included choosing papers based on the title and abstract. When every one of the titles was chosen, duplicates were removed. Irrelevant studies were disregarded. If there was any vulnerability about the significance of a study, the entire paper was read. The search strategy was modified to suit different databases. The following electronic databases were searched in May 2019: Medline, Amed, Cinahl, PubMed, PsychInfo, Cochrane Library, and Physiotherapy Evidence database (PEDro), and the search was expanded with the following references lists from selected articles.

The design of the study (controlled randomized trial), participants (people with PD), type of the treatment (compare the effect of a physiotherapy intervention to any comparable including other physiotherapy intervention), type of outcomes (report the effect of physiotherapy on fall and/or at least one fall risk factor), language (written in English), and availability of the full text were important and needed to be considered to find the most relevant studies.

The researcher independently extracted data from the studies by using a standard data extraction form. An outline of all the included material was condensed in a table that maps the literature. The literature was organized and presented in relation to the author, location, and year of publication; aim; method; outcome measures; and results. 


\section{Findings}

A total of 173 papers were identified before 25 duplicates were discarded. Following the screening of the titles and abstracts, 66 studies remained. In total, a further 29 papers were excluded after screening of full text and inclusion criteria, leaving 37 papers eligible for inclusion. Two further papers were identified by hand searching; therefore, in total, 39 papers were included in this scoping review (Fig. 1). Fifteen of the included papers reported the direct effects of physiotherapy interventions on fall and furthermore inspected the effects on other risk factors, whereas the rest of the studies did not examine the benefits of physiotherapy interventions on fall directly. Rather, they announced different variables related with fall, for example, balance, functional mobility, and gait as end points.

\section{Studies reporting both fall incidence and fall risk factors}

The scoping search yielded 15 considered studies containing data important to the direct effect of physiotherapy intervention on fall rate and near fall incidence (Table 1). Different physiotherapy interventions, duration and outcomes were used in these studies.
The sample sizes reported, with included studies, ranged from 18 [14] to 474 [4]. Eight studies [14-18] included 100 participants or less, and only 4 studies [19-22] had an initial sample size of between 130 and 195 participants. Therefore, the rest 3 studies $[4,23,24]$ had an initial sample size of between 210 and 474 participants. Every included study in this part recorded the quantity of falls/near fall incidence or fear of falling. These studies recorded falls utilizing falls diary sheet, which is the best gold standard in view of participants/ family $[4,15-17,20-22,25,26]$, telephone interviews [14, 19, 24-26], or medical record observation [23].

Falls were reported at set of intervals, ranging 1-month [26], 8-week [14], 10-week [19]; 3-month [22], 6-month $[15,17,20,21,23,25]$, or over 12 -month period intervals $[4,6,24]$.

These papers also include a variety of interventions related to the field of physiotherapy including traditional physiotherapy exercises, movement, and strategy training. In this way, this paper may give a far-reaching outline about the advantages of physiotherapy as far as fall risk decreases in individuals with PD. For example, the effect of exercise training [4, $14,19,21,24]$ and balance training exercise $[16,23,24]$ for fall prevention in PD has been tested in some studies.

The results of included studies reported that there are no benefits of exercise training for fall preventions $[4,14,19,21$,

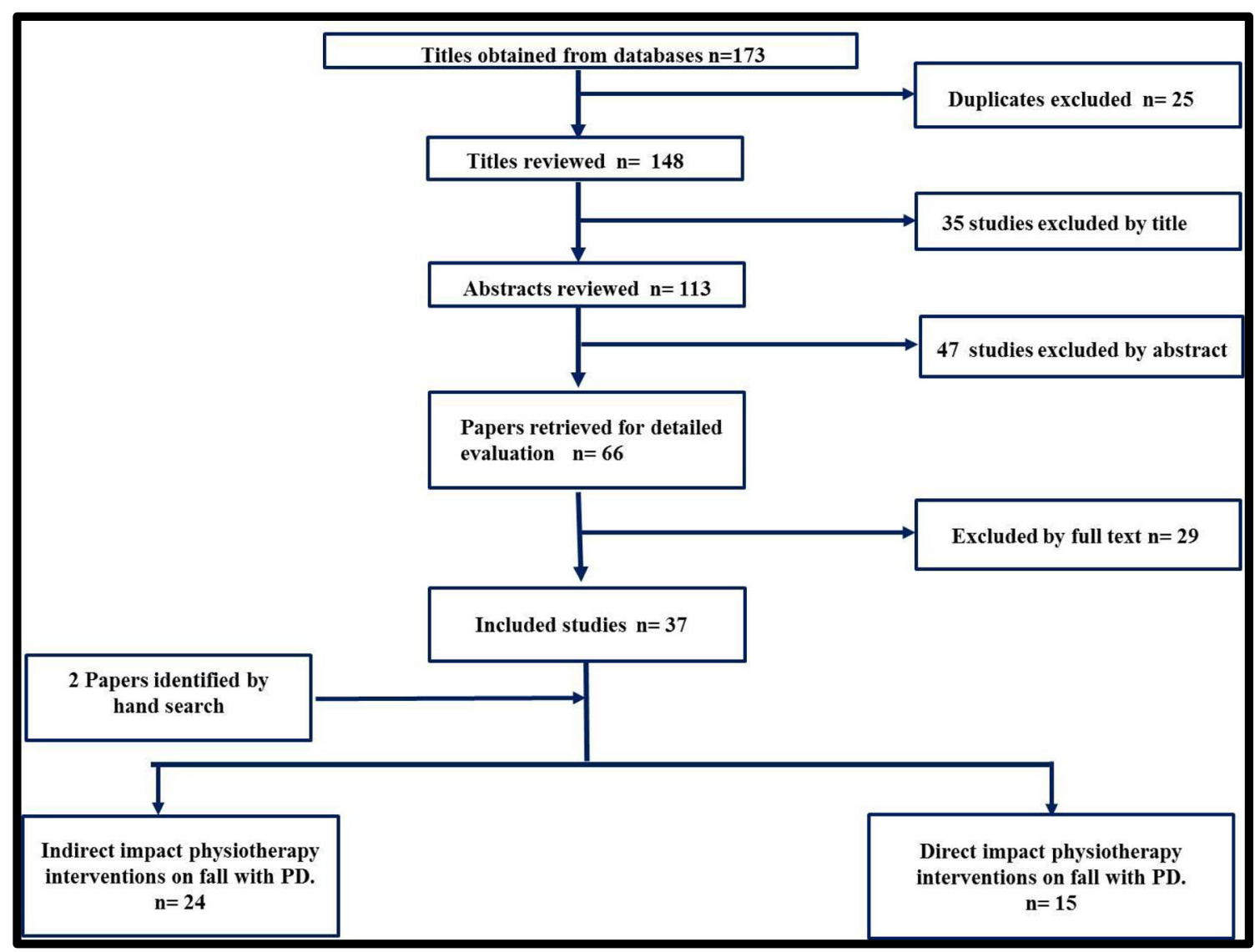

Fig. 1 Flowchart showing the results of the scoping review 
Table 1 Studies of direct impact of physiotherapy intervention on fall

\begin{tabular}{|c|c|c|c|c|}
\hline Author/Year/Location & Aim & Method & Outcome measures & Result/conclusion \\
\hline $\begin{array}{l}\text { Seymour et al (2019) } \\
\text { The UK }\end{array}$ & $\begin{array}{l}\text { To investigate the } \\
\text { general potential } \\
\text { benefits of fall } \\
\text { prevention } \\
\text { physiotherapy } \\
\text { programme on } \\
\text { people with PD }\end{array}$ & $\begin{array}{l}\text { RCT } \\
474 \text { PD patients } \\
\text { randomly allocated } \\
\text { into : } \\
\text { Experimental } \\
\text { group(n=238): } \\
\text { People in this group } \\
\text { were taught } \\
\text { different home } \\
\text { exercises aiming at } \\
\text { fall avoidance and } \\
\text { improving balance } \\
\text { and strengthening } \\
\text { exercise. } \\
\text { Control group } \\
\text { (n=236): } \\
\text { Participants in this } \\
\text { group received } \\
\text { DVD that might } \\
\text { have involved } \\
\text { instructions on falls } \\
\text { rehabilitation } \\
\text { therapy supervised } \\
\text { 12 sessions of } 1-1.5 \\
\text { sess for a duration } \\
\text { hours for } \\
\text { of Six months. }\end{array}$ & $\begin{array}{l}\begin{array}{l}\text { Primary outcome: } \\
\text { Risk of repeat } \\
\text { falling: (self- } \\
\text { report diaries). }\end{array} \\
\text { Secondary } \\
\text { outcomes: } \\
\quad \text { Mini- } \\
\quad \text { BESTest: } \\
\text { (balance). } \\
\quad \text { Chair stand } \\
\quad \text { test. } \\
\quad \text { FES1 } \\
\quad \text { FOG. } \\
\text { Different outcomes } \\
\text { related to fall were } \\
\text { assessed at three } \\
\text { different points, i.e., } \\
\text { before } \\
\text { randomization, at } \\
\text { the end of the study } \\
\text { (6 months) and at } \\
12 \text { months after the } \\
\text { study to follow up }\end{array}$ & 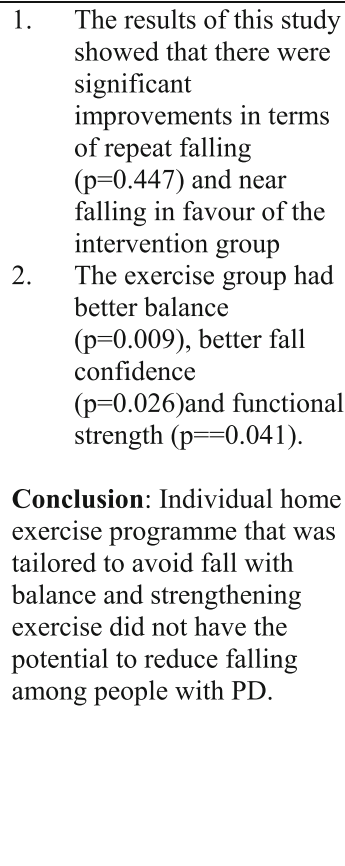 \\
\hline $\begin{array}{l}\text { Thaut et al., (2018) } \\
\text { Canada }\end{array}$ & $\begin{array}{l}\text { To determine } \\
\text { whether or not } \\
\text { rhythmic auditory } \\
\text { stimulation(RAS) } \\
\text { training is beneficial } \\
\text { for fall reductions in } \\
\text { people with PD }\end{array}$ & $\begin{array}{l}\text { RCT } \\
60 \text { PD patients } \\
\text { randomised into: } \\
\text { Experimental } \\
\text { group }(\mathrm{n}=30): \\
\text { subjects were asked } \\
\text { to complete the } \\
\text { RAS training } \\
\text { exercises on a daily } \\
\text { basis for } 24 \text { weeks. } \\
\text { Control } \\
\text { group }(\mathrm{n}=30) \text { : Usual } \\
\text { care }\end{array}$ & $\begin{array}{l}\text { Main outcome } \\
\text { measures: } \\
\quad \text { BBS } \\
\text { TUG } \\
\text { Falls efficacy } \\
\text { scale } \\
\text { The fall index. } \\
\text { Outcome measures } \\
\text { were collected at } \\
\text { baseline, } 8^{\text {th }}, 16^{\text {th }} \\
\text { and } 24^{\text {th }} \text { weeks. }\end{array}$ & $\begin{array}{l}\text { 1. At week 8: No } \\
\text { significant improvement } \\
\text { was noticed between } \\
\text { groups. } \\
\text { 2. After 16 weeks: The } \\
\text { RAS group gained } \\
\text { significant } \\
\text { improvements in terms } \\
\text { of fall index and FOF. } \\
\text { At week 24: There was } \\
\text { a significant } \\
\text { improvement in RAS } \\
\text { training group in term } \\
\text { of FOF and number of } \\
\text { falls.. } \\
\text { Conclusion: RAS training } \\
\text { program was beneficial to } \\
\text { reduce the number of falls in } \\
\text { PD. }\end{array}$ \\
\hline Sparrow et al (2016) & $\begin{array}{l}\text { To investigate the } \\
\text { benefits of } \\
\text { physiotherapy } \\
\text { exercise program } \\
\text { intervention on fall } \\
\text { rate, balance, and } \\
\text { fear of falling in } \\
\text { patient with PD. }\end{array}$ & $\begin{array}{l}\text { RCT } \\
23 \text { subjects with PD } \\
\text { were consequently } \\
\text { placed into } 3 \text { months } \\
\text { of active balance } \\
\text { exercise or } 3 \\
\text { months of inactivity } \\
\text { (usual care) } \\
\text { followed by the } \\
\text { reserve. } \\
\text { The program was } \\
\text { held twice weekly } \\
/ 90 \text { minutes } / 3 \\
\text { months. }\end{array}$ & $\begin{array}{l}\frac{\text { Main outcome }}{\text { measures: }} \\
\text { Falls } \\
\text { Balance: } \\
\text { (Mini- } \\
\text { BESTest). } \\
\text { Fear of } \\
\text { falling: (FES- } \\
\text { 1). } \\
\text { Assessment: } \\
\text { baseline, } 3 \text { months, } \\
\text { and at } 6 \text { months. }\end{array}$ & $\begin{array}{l}\text { 1. There was an evidence } \\
\text { to support the effects of } \\
\text { physiotherapy } \\
\text { interventions on } \\
\text { decreasing fall rate } \\
(37 \%) \text { per month . } \\
\text { 2. Significant } \\
\text { improvements were } \\
\text { noted in terms of Mini- } \\
\text { BESTest ( } \mathrm{p}=0.037) \text { and } \\
\text { FES-1 ( } \mathrm{p}=0.059) \text {. } \\
\text { Conclusion: Progressive } \\
\text { exercise programs could } \\
\text { demonstrate significant } \\
\text { improvement in reducing the } \\
\text { number of falls, improving } \\
\text { balance and FOF with mild to } \\
\text { moderate PD. }\end{array}$ \\
\hline $\begin{array}{l}\text { Wong-Yu and Mak } \\
\text { (2015) } \\
\text { China }\end{array}$ & $\begin{array}{lr}\text { To examine the } \\
\text { short/long } & \text { term } \\
\text { effects of balance } \\
\text { training }\end{array}$ & $\begin{array}{l}\mathrm{RCT} \\
70 \mathrm{PD} \text { randomly } \\
\text { allocated into: } \\
\text { Experimental group }\end{array}$ & $\begin{array}{l}\text { Primary outcome } \\
\text { measures: } \\
\begin{array}{l}\text { Balance } \\
\text { (Mini- }\end{array}\end{array}$ & $\begin{array}{l}\text { Fall at follow up: } \\
\text { 1- } \\
\begin{array}{l}\text { No significant } \\
\text { improvement between } \\
\text { groups was noticed in }\end{array}\end{array}$ \\
\hline
\end{tabular}




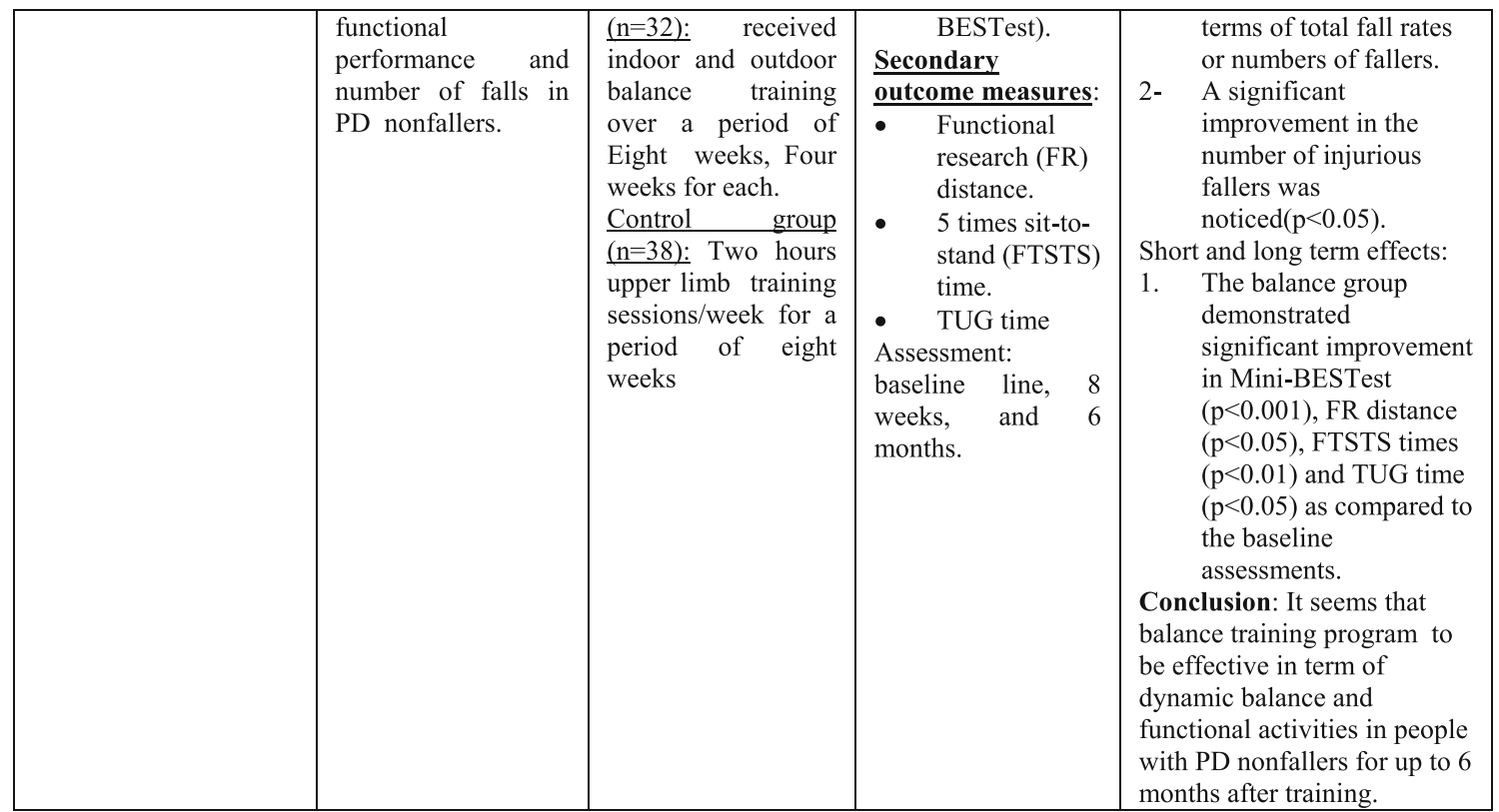

PD: Parkinson's disease; RCT: Randomized controlled trial ; BESTest: Balance evaluation system test; FES-1: Falls efficacy scale-international score; FOG: Freezing of gait; BBS: Berg balance scale; TUG: Timed up and go; TUG: Timed-up- and go; FOF: fear of falling

\section{Table 1: Studies of direct impact of physiotherapy intervention on fall (Con).}

\begin{tabular}{|c|c|c|c|c|}
\hline Author/Year/Location & Aim & Method & Outcome measures & Result/conclusion \\
\hline $\begin{array}{l}\text { Shen and Mak (2015) } \\
\text { China }\end{array}$ & $\begin{array}{l}\text { To investigate } \\
\text { the effects of } \\
\text { technology- } \\
\text { assisted } \\
\text { balance and } \\
\text { gait training on } \\
\text { fall reduction } \\
\text { in people with } \\
\text { PD. }\end{array}$ & $\begin{array}{l}\text { RCT } \\
51 \text { subjects were randomly } \\
\text { assigned to either: } \\
\text { Experimental(BAL)group } \\
\text { (n=26):technology-assisted } \\
\text { balance and gait training. } \\
\text { Control group }(\mathrm{n}=25) \text { : } \\
\text { strengthening exercise. } \\
\text { Both groups receiving } \\
\text { training for } 12 \text { weeks. }\end{array}$ & 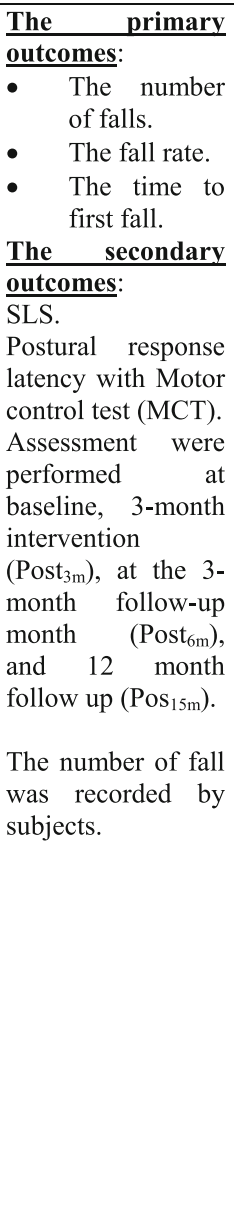 & 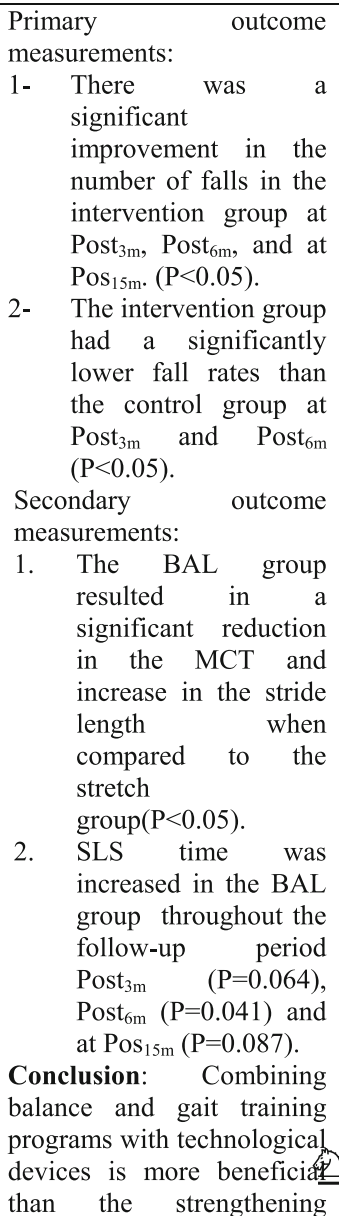 \\
\hline
\end{tabular}




\begin{tabular}{|c|c|c|c|c|}
\hline & & & & $\begin{array}{l}\text { training program only to } \\
\text { reduce the number of fallers } \\
\text { and fall rate over } 15 \\
\text { months in people with PD. }\end{array}$ \\
\hline $\begin{array}{l}\text { Morris et al (2015) } \\
\text { Australia }\end{array}$ & $\begin{array}{l}\text { To examine the } \\
\text { benefits of } \\
\text { progressive } \\
\text { resistance } \\
\text { strength } \\
\text { training } \\
\text { (PRST) or } \\
\text { movement } \\
\text { strategy } \\
\text { training (MST) } \\
\text { on fall rate in } \\
\text { people with PD } \\
\text { over } \\
\text { months. } 12\end{array}$ & $\begin{array}{l}\text { RCT } \\
210 \text { people with PD were } \\
\text { allocated randomly into: } \\
\text { Group1(PRST, } \mathrm{n}=70 \text { ): } \\
\text { Received progressive } \\
\text { resistance strength training } \\
\text { with education classes about } \\
\text { falls prevention. } \\
\text { Group } 2 \text { (MST, } \mathrm{n}=69 \text { ): } \\
\text { Received movement strategy } \\
\text { training combined with fall } \\
\text { prevention programmes } \\
\text { Group } 3 \text { (Control group, } \\
\mathrm{n}=71 \text { ): life skill information. } \\
2 \text { hour therapy/per week/for } \\
8 \text { weeks }\end{array}$ & $\begin{array}{l}\text { Primarv outcome: } \\
\text { - Falls rate. } \\
\text { Secondary } \\
\text { outcome } \\
\text { measures. } \\
\text { - UPDRS } \\
\text { - TUG test } \\
\quad \text { VAS } \\
\text { Outcome measures } \\
\text { were collected at } \\
\text { baseline, } 8^{\text {th }} \text { week, } \\
3 \text { months and } 12 \\
\text { months after } \\
\text { treatment. } \\
\text { falls were taken } \\
\text { using interviews } \\
\text { with participants. }\end{array}$ & $\begin{array}{l}\text { 1. The results showed } \\
\text { that } 193 \text { falls were } \\
\text { recorded for PRST } \\
\text { group, 441 falls for } \\
\text { MST group and } 913 \\
\text { falls for the control } \\
\text { group over the period } \\
\text { of } 12 \text { months. } \\
\text { The results showed } \\
\text { that, compared to the } \\
\text { control group, both } \\
\text { PRST and MST } \\
\text { groups had led to a } \\
\text { significant } \\
\text { improvements in terms } \\
\text { of falls (P }<0.001 \text {, } \\
\text { P=0.012 respectively) } \\
\text { For the } 12 \text {-month follow-up } \\
\text { test: } \\
\text { Both PRST and MST } \\
\text { interventions resulted } \\
\text { in significant positive } \\
\text { impacts on UPDRS } \\
\text { activities compared } \\
\text { with control group } \\
\text { (P }<0.01 \text { and P }<0.01 \\
\text { respectively). Also, } \\
\text { The MST group led to } \\
\text { significant } \\
\text { improvement in the } \\
\text { UPDRS motor score } \\
\text { compared with control } \\
\text { group (P=0.017). } \\
\text { No difference between } \\
\text { group for TUG from } \\
\text { baseline to } 12 \text { month. } \\
\text { Conclusion: Fall prevention } \\
\text { programmes with strength } \\
\text { training or movement } \\
\text { strategy training has the } \\
\text { potential to significantly } \\
\text { reduce the rate of falls } \\
\text { among people with mild to } \\
\text { moderately PD }\end{array}$ \\
\hline $\begin{array}{l}\text { Martin et al., (2015) } \\
\text { New Zealand }\end{array}$ & $\begin{array}{l}\text { To examine the } \\
\text { effects of } \\
\text { cueing training } \\
\text { program on } \\
\text { falls in PD } \\
\text { with FOG. }\end{array}$ & $\begin{array}{l}\text { RCT } \\
29 \text { participants with PD were } \\
\text { randomised into: } \\
\text { The first group }(\mathrm{n}=12) \text { : } \\
\text { received cueing training } \\
\text { sessions for six home visits } \\
\text { within the first } 4 \text { weeks over } \\
\text { a period of } 6 \text { months, } \\
\text { followed by weekly phone } \\
\text { calls for the remaining } 5 \\
\text { months. } \\
\text { The second group ( }=9) \text { : } \\
\text { People in this group of the } \\
\text { study were asked to wait } 6 \\
\text { months and after the } 6 \\
\text { months they immediately } \\
\text { started their cueing training. }\end{array}$ & $\begin{array}{l}\text { Main outcomes: } \\
\begin{array}{l}\text { NFOGQ. } \\
\text { Number of } \\
\text { fall: daily } \\
\text { diary. }\end{array} \\
\text { The assessments } \\
\text { were taken at 2 } \\
\text { weeks after the end } \\
\text { of study. }\end{array}$ & $\begin{array}{l}\text { 1. The results showed } \\
\text { that the intervention } \\
\text { had not led to } \\
\text { significant differences } \\
\text { in NFOGQ total } \\
\text { scores ( } \mathrm{P}=0.70) \text {, fall } \\
\text { rate }(\mathrm{P}=0.008) \text { and } \\
\text { FOG }(\mathrm{P}=0.63) \\
\text { between groups after } \\
\text { intervention } \\
\text { Conclusion: Cued up } \\
\text { intervention is acceptable } \\
\text { and may improve falls and } \\
\text { FOG in people with PD. } \\
\text { however, further investigate } \\
\text { is needed with large sample } \\
\text { size. }\end{array}$ \\
\hline
\end{tabular}

PD: Parkinson's disease; RCT: Randomized controlled trial ; SLS: Single-leg-stance ; NFOGQ: New freezing of gait questionnaire; UPDRS: Unified Parkinson's disease rating scale; TUG: Timed up and go; VAS: Visual analogue scale. 


\begin{tabular}{|c|c|c|c|c|}
\hline Author/Year/Location & Aim & Method & Outcome measures & Result/conclusion \\
\hline $\begin{array}{l}\text { Canning et al, (2015) } \\
\text { Australia }\end{array}$ & $\begin{array}{l}\text { To examine the effect of } \\
\text { supervised exercise on } \\
\text { fall and a number of fall } \\
\text { risk factors, namely } \\
\text { balance , muscle } \\
\text { strength, and FOG in } \\
\text { people with PD. }\end{array}$ & $\begin{array}{l}\text { RCT } \\
\text { 231 PD allocated randomly into: } \\
\text { Intervention group ( } \mathrm{n}=115): 6 \text { month } \\
\text { exercise program + falls prevention } \\
\text { advice. } \\
\text { Control group ( } \mathrm{n}=116) \text { : Fall } \\
\text { prevention advice only. } \\
\text { Exercises were practiced } 40-60 \\
\text { minutes/3times/week/ for } 6 \text { months. }\end{array}$ & $\begin{array}{l}\text { Primary outcome measures: } \\
\text { Number of falls. } \\
\text { The proportion of fallers of participants } \\
\text { during the study period. } \\
\text { Secondary outcome: } \\
\text { The PD fall risk score. } \\
\text { Mean knee extensor muscle strength. } \\
\text { The short physical performance battery } \\
\text { (walking, standing balance, and sit to } \\
\text { stand. }\end{array}$ & 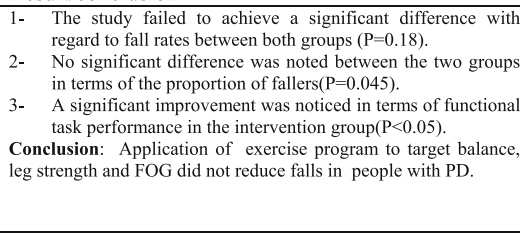 \\
\hline $\begin{array}{l}\text { Gao et al., (2014) } \\
\text { China }\end{array}$ & $\begin{array}{l}\text { To compare the effects } \\
\text { of group-based tai chi } \\
\text { exercise, and a control } \\
\text { condition group on fall } \\
\text { prevention in PD. }\end{array}$ & $\begin{array}{l}\text { RCT } \\
76 \text { PD randomly allocated into: } \\
\text { Experimental group }(\mathrm{n}=37): \text { Tai } \mathrm{Chi} \\
\text { Control group }(\mathrm{n}=39): \text { no intervention } \\
36 \text { sessions } / 60 \text { minutes each time/for } \\
12 \text { weeks. }\end{array}$ & $\begin{array}{l}\text { Main outcomes: } \\
\text { - Motor function: UPDRS. } \\
\text { Balance: BBS. } \\
\text { Outcomes were assessed at two different points, } \\
\text { i.e., before randomization, at the end of the } \\
\text { study(12 weeks). } \\
\text { All participants were assessed at } 6 \text { months after } \\
\text { the study to follow up to assess the fall. }\end{array}$ & 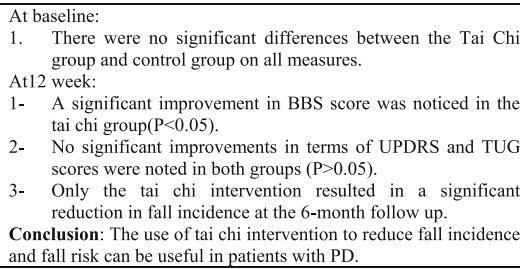 \\
\hline $\begin{array}{l}\text { Li et al., (2012) } \\
\text { US }\end{array}$ & $\begin{array}{l}\text { To compare the effects } \\
\text { of Tai chi exercise with } \\
\text { the effect of resistance- } \\
\text { training or stretching } \\
\text { exercise to improve } \\
\text { postural control in } \\
\text { Parkinson's disease. }\end{array}$ & $\begin{array}{l}\text { RCT } \\
\text { Participants }(\mathrm{n}=195) \text { were randomly } \\
\text { assigned to one of these three groups: } \\
\text { Tai Chi group }(\mathrm{n}=65) \text { : The tai chi } \\
\text { intervention consisted of twice weekly } \\
\text { classes for twenty-four weeks, with } \\
\text { each class lasting for an hour. } \\
\text { Resistant training group (n=65): } \\
\text { strengthening exercises targeting } \\
\text { those muscles responsible for } \\
\text { improving balance, gait and posture. } \\
\text { Control group (n=65): Stretching } \\
\text { group }\end{array}$ & $\begin{array}{l}\text { Primary outcomes: } \\
\text { Postural stability: Two indicators of } \\
\text { postural stability (maximum excursion and } \\
\text { directional control). } \\
\text { Secondary outcomes: } \\
\text { Gait: (stride length and walking velocity). } \\
\text { Muscle strength. } \\
\text { Static balance. } \\
\text { TUG. } \\
\text { Outcome measures were repeated at } 3 \text { different } \\
\text { times: at baseline, at } 3 \text { and } 6 \text { months }\end{array}$ & $\begin{array}{l}\text { The results revealed that significant improvements in terms } \\
\text { of gait velocity, gait parameters, muscle strength, balance and } \\
\text { functional mobility measures were noted in both the tai chi } \\
\text { and the resistance groups as compared to the stretch group. } \\
\text { 2- Only the tai chi intervention resulted in a significant } \\
\text { reduction in fall rates when compared to the stretch group. } \\
\text { 3- The performance of the people in tai chi significantly } \\
\text { outweighed the performance of those in the resistance group } \\
\text { in terms of stride length and balance. } \\
\text { The improvements in the tai chi group remained at the same } \\
\text { level even at three months after the end of the intervention. } \\
\text { Conclusion: Tai chi training appears to reduce balance } \\
\text { impairments, improve functional capacity and reduced falls in } \\
\text { patients with mild to moderate PD. }\end{array}$ \\
\hline $\begin{array}{l}\text { Goodwin et al., (2011) } \\
\text { UK }\end{array}$ & $\begin{array}{l}\text { To compare the effects } \\
\text { of ten sessions of group- } \\
\text { based intervention, } \\
\text { including strength and }\end{array}$ & $\begin{array}{l}\text { RCT } \\
130 \text { participants were randomly } \\
\text { allocated into } \\
\text { Intervention group }(\mathrm{n}=64) \text { : }\end{array}$ & $\begin{array}{l}\text { Primary outcome: } \\
\text { The number of falls/fall rates. } \\
\text { Secondary outcomes: } \\
\quad \text { FESI; }\end{array}$ & $\begin{array}{l}\text { 1. No significant different in falls between groups. } \\
\text { 2. Significant different was observed in BBS and FESI at the } \\
\text { 10 week follow-up. } \\
\text { 3. There were significant improvements in terms of balance, }\end{array}$ \\
\hline & $\begin{array}{l}\text { balance exercise with } \\
\text { regular care, on fall } \\
\text { rates and fall risks in } \\
\text { people with PD }\end{array}$ & $\begin{array}{l}\text { Received a group exercise programme } \\
\text { that commenced in five different } \\
\text { community settings with twice- } \\
\text { weekly home exercise programme. } \\
\text { Control group ( } \mathrm{n}=66 \text { ): usual care. } \\
\text { One hour/week/for } 10 \text { weeks. }\end{array}$ & $\begin{array}{l}\text { - } \quad \text { EuroQOL-5D } \\
\text { Phone-FITT } \\
\text { BBS } \\
\text { TUG } \\
\text { Assessments were completed at baseline, post } \\
\text { intervention, and follow up (10 weeks) }\end{array}$ & $\begin{array}{l}\text { functional mobility and FOF in favour of the intervention } \\
\text { group. } \\
\text { Conclusion: The study did not demonstrate a statistically } \\
\text { significant between group differences in fall. }\end{array}$ \\
\hline
\end{tabular}
PD: Parkinson's disease; RCT: Randomized controlled trial; FESI: Falls efficacy scale-international questionnaire; BBS: Berg balance scale; TUG: Timed up and go ; UPDRS: Unified Parkinson's disease rating scale; QOL-5D: Quality of life; FOF: fear of falling..

23]. However, some studies reported significant reduction in falls when exercise containing strength and/or balance exercises $[16,18,24,26]$. Additionally, two randomized trials [20, 27] analyzed the impacts of tai chi exercise on fall decrease in individuals with PD. The discoveries demonstrated that tai chi exercise had positive effects on reducing future falls.

The effectiveness of rhythmic auditory stimulation (RAS) has been resulted in decreasing the number of falls in PD disease $[15,22,25]$. Two RCTs reported that RAS concluded that RAS training significantly reduced the number of falls in PD [15, 22], whereas one RCT study [25] reported that RAS did not have important changes in falls in people with PD.

Furthermore, the interventions of the above studies led to significant improvement in terms of balance $[4,15-17,19-22$, 27] functional mobility [4, 15, 17-20, 23], Fear of falling (FOF) [16, 19, 23, 26], fall rates [14, 17, 18, 21, 24, 25], serious injuries associated with falls $[17,21]$, freezing of gait (FOG) [4, 22, 25], and gait parameters [14, 15, 17, 18, 20, 22]. Nonetheless, the resulting measures in most of these studies were assessed following the treatment.

Just a couple of studies had follow-up evaluations. However, these studies had short follow-up periods. In this way, it is difficult to give an end with respect to the long-haul impacts of physiotherapy on fall risk reduction. Only three studies had a 1-year follow-up period, and the results showed that strength movement strategy training and multidimensional balance training could reduce the rate of falls in people with mild to moderate PD [4, 18, 24].

\section{Interventions that reported fall risk factors only}

Rather than the studies evaluated in the segment above, there are various studies that neither target fallers nor report fall number or close fall rate as results (Table 2). However, these studies examined the impacts of physiotherapy interventions on several factors that are closely associated with fall in people with PD, such as balance, functional task, gait, and muscle strength.

\section{Effect of balance}

The significance of balance in fall avoidance is featured. In this scoping review, a few studies detailed the impact of physiotherapy intervention on balance [28-44].

Fourteen studies out of the 17 papers that reported on balance showed physiotherapy intervention had led to a statistically significant improvement in at least one of the balance measures as compared to either control or active interventions [28-34, 36, 37, 39, 40, 42-44]. However, only three 
Table 2 Studies of indirect effects of physiotherapy on fall

\begin{tabular}{|c|c|c|c|c|}
\hline Author/Year/location & Aim & Method & Outcome measures & Result \\
\hline $\begin{array}{l}\text { Sliva-Batista et al (2018) } \\
\text { Brazil }\end{array}$ & $\begin{array}{l}\text { To examine the effect of } \\
\text { resistance training with } \\
\text { instability (RTI) and } \\
\text { resistance training (RT) } \\
\text { on balance and FOF in } \\
\text { patients with PD. }\end{array}$ & $\begin{array}{l}\text { RCT } \\
39 \text { subjects with PD randomly } \\
\text { allocated into: } \\
\text { Experimental group }(\mathrm{n}=26) \text { : } \\
\text { Exercise training }(\mathrm{RT} n=13 ; \text { RTI } \\
\mathrm{n}=13) \text {. } \\
\text { Control group }(\mathrm{n}=13) \text { : received no } \\
\text { exercise training. }\end{array}$ & $\begin{array}{l}\text { Main outcome measures: } \\
\text { Balance: (BESTest) } \\
\text { Tests were repeated at two different points: at } \\
\text { baseline and after three months (12 weeks). }\end{array}$ & $\begin{array}{l}\text { A significant improvement in balance and FOF was noticed in } \\
\text { experimental group. However, this improvement was more } \\
\text { effective in RTI than } \mathrm{RT}(\mathrm{P}<0.05) \text {. } \\
\text { Conclusion: Authors concluded that RTI has the potential to } \\
\text { significantly improve balance and FOF among people with PD. }\end{array}$ \\
\hline $\begin{array}{l}\text { Conradsson et al., (2015) } \\
\text { Sweden }\end{array}$ & $\begin{array}{l}\text { To examine the effects } \\
\text { of } \\
\text { of a ten week of balance } \\
\text { program in people with } \\
\text { PD. }\end{array}$ & $\begin{array}{l}\text { RCT } \\
\text { Participant with PD }(\mathrm{n}=100) \text { were } \\
\text { randomised into } \\
\text { Experimental group }(\mathrm{n}=51) \\
\text { HiBalance program. } \\
\text { Control group }(\mathrm{n}=49) \text { : Usual care } \\
\text { The balance group training was } \\
\text { performed:3times } / \text { week } / 60 \text { minutes } \\
\text { per session } / 10 \text { weeks. }\end{array}$ & $\begin{array}{l}\text { The main outcomes: } \\
\text { Balance: Mini-BESTest. } \\
\text { Gait velocity: during normal and dual- } \\
\text { task(DT) gait. } \\
\text { Falling: FES-1. } \\
\text { Different outcomes related to fall and fall risk } \\
\text { factors were assessed at two different points, } \\
\text { i.e., before randomization and at the end of the } \\
\text { study. }\end{array}$ & $\begin{array}{l}\text { 1- The results showed that there was a significant improvement in } \\
\text { terms of balance }(\mathrm{P}=0.001) \text { in favour of the experimental group. } \\
\text { 2- As compared to the control group, the experimental group } \\
\text { gained significant improvements in terms of DT gait. However, } \\
\text { no significant effect of training for concerns about falling. } \\
\text { Conclusion: The HiBalance program has the potential to significantly } \\
\text { improve balance and gait abilities in patients with PD. However, no } \\
\text { benefit was found for concern about falling }\end{array}$ \\
\hline $\begin{array}{l}\text { Wong-Yu and Mak (2015) } \\
\text { China }\end{array}$ & $\begin{array}{l}\text { To investigate the direct } \\
\text { effect of multi- } \\
\text { dimensional blended } \\
\text { indoor and outdoor } \\
\text { (BIO) balance training } \\
\text { intervention in balance } \\
\text { in people with PD. }\end{array}$ & $\begin{array}{l}\text { RCT } \\
84 \text { PD randomly allocated into: } \\
\text { Experimental group }(\mathrm{n}=41) \text { : } \\
\text { completed } 4 \text { - week indoor and } 4- \\
\text { week outdoor balance training. } \\
\text { Control group }(\mathrm{n}=39) \text { : completed } \\
8 \text { weeks upper limb training. }\end{array}$ & $\begin{array}{l}\text { The primary outcome: } \\
\text { Balance: (BESTest). } \\
\text { The secondary outcome measures: } \\
\text { Gait speed. } \\
\text { TUG. } \\
\text { Assessment were occurred at baseline, post- } \\
\text { training assessment, } 6 \text { month follow-up } \\
\text { assessment and } 12 \text { month follow -up } \\
\text { assessment. }\end{array}$ & $\begin{array}{l}\text { 1. Short term effect: There were significant improvements in terms } \\
\text { of BESTest total score }(\mathrm{p}<0.001) \text {, gait speed }(\mathrm{p}<0.05) \text {, and } \\
\text { TUG ( }<00.01 \text { ) from baseline in favour of the experimental } \\
\text { group. } \\
\text { 2. Long term effect: the experimental group had significantly } \\
\text { increases in the BESTest total score ( } \mathrm{p}<0.001 \text { ), gait speed } \\
\text { ( }<0.05 \text { ) and TUG }(\mathrm{p}<0.05 \text { ) than control group. } \\
\text { Conclusion: multi-dimensional balance training programme has the } \\
\text { potential to significantly improve balance and dual-task gait } \\
\text { performance up to } 12 \text { months among people with PD. }\end{array}$ \\
\hline $\begin{array}{l}\text { Volpe et al., (2014) } \\
\text { Italy }\end{array}$ & $\begin{array}{l}\text { To compare the effects } \\
\text { of hydrotherapy } \\
\text { treatment on balance } \\
\text { with regular care in } \\
\text { people with PD. }\end{array}$ & $\begin{array}{l}\text { RCT } \\
\text { Experimental group }(\mathrm{n}=17) \text { : } \\
\text { Hydrotherapy. } \\
\text { Control group }(\mathrm{n}=17) \text { : land-based } \\
\text { standard rehabilitation. } \\
60 \text { minutes } / 5 \text { weeks } / 2 \text { months. }\end{array}$ & $\begin{array}{l}\text { The main outcomes were: } \\
\text { UPDRS } \\
\text { BBS } \\
\text { Falls efficacy scale } \\
\text { Assessment was occurred at baseline, and one } \\
\text { week after rehabilitation. }\end{array}$ & $\begin{array}{l}\text { At } 10 \text { week after rehabilitation: } \\
1 \text { - By the end of the rehabilitation protocol, the hydrotherapy } \\
\text { group gained significant improvements in terms of } B B S \\
\text { ( } P=0.005) \text {, falls efficacy scale }(\mathrm{P}=0.003) \text {, falls diary ( } \mathrm{P}=0.001) \text {. } \\
\text { Conclusion: Hydrotherapy treatment was beneficial to address } \\
\text { balance, postural stability and reducing falls rate in people with } \\
\text { moderate stage of PD. }\end{array}$ \\
\hline $\begin{array}{l}\text { Duncan and Earhart (2012) } \\
\text { USA }\end{array}$ & $\begin{array}{l}\text { To explored the effect of } \\
\text { a twice weekly tango } \\
\text { programme conducted } \\
\text { over a period of one year } \\
\text { for individuals with PD. }\end{array}$ & $\begin{array}{l}\text { Sixty-two patient with PD } \\
\text { divided: } \\
\text { Intervention group }(\mathrm{n}=26) \text { : } \\
\text { Community based Argentine } \\
\text { Tango program( } 2 \text { sessions } / 60 \\
\text { minutes/week/ for } 12 \text { months). }\end{array}$ & $\begin{array}{l}\text { Primary outcome: } \\
\text { - MDS-UPDRS-3. } \\
\text { Secondary outcome: } \\
\quad \text { MDS-UPDERS-1. } \\
\text { MDS-UPDRS- } 2 \text {. }\end{array}$ & $\begin{array}{l}\text { 1- After one year, the results revealed that the intervention group } \\
\text { gained significant improvements in all outcome measures, as } \\
\text { compared to baseline and to the control group ( } \mathrm{P}=0.001) \text {. } \\
\text { Conclusion: These positive results provide strong evidence for the } \\
\text { efficacy of long term participation in tango in patients with PD. }\end{array}$ \\
\hline
\end{tabular}

\begin{tabular}{|l|l|l|l|l|}
\hline & & Control group (n= 26 ): No & $\begin{array}{l}\text { MiniBESTest balance test. } \\
\text { intervention }\end{array}$ & $\begin{array}{l}\text { FOG questionnaire } \\
6 \text { GWT. } \\
\text { Giat velocity. } \\
\text { 9HPT. } \\
\text { Outcome measures were applied before the } \\
\text { study (at baseline), 3,6, and 12 months. }\end{array}$ \\
\hline PD: Parkinson's disease; RCT: Randomized controlled trial; BBS: Berg balance scale; UPDRS: Unified Parkinson's disease rating scale; TUG: Timed up and go; BESTest: balance evaluation systems test ; FES-1:
\end{tabular}

PD: Parkinson's disease ; RCT: Randomized controlled trial; BBS: Berg balance scale; UPDRS: Unified Parkinson's disease rating scale; TUG: Timed up and go; BESTest: balance evaluation systems test ; FES-1: Falls efficacy scale-international; FOG: Freezing of gait; 6MWT: Six minute walk; 9HPT: Nine Hole Peg Test; MDS-UPDERS3: Movement disorders society-unified Park
UPDERS2: Movement disorders society-unified Parkinson's disease rating scale 2; MDS-UPDERS1: Movement disorders society-unified Parkinson's disease rating scale 1

Table 2: Studies reported indirect effects of physiotherapy on fall(cont.).

\begin{tabular}{|c|c|c|c|c|}
\hline Author/Year/location & Aim & Method & Outcome measures & Result \\
\hline $\begin{array}{l}\text { Stack et al (2012) } \\
\text { UK }\end{array}$ & $\begin{array}{l}\text { To explore the effects of four } \\
\text { weeks of a home- based } \\
\text { physiotherapy programme } \\
\text { consisting of exercises and } \\
\text { movement training strategies } \\
\text { on two fall risk factors, namely } \\
\text { balance and functional } \\
\text { mobility. }\end{array}$ & $\begin{array}{l}\text { RCT } \\
\text { A total of } 47 \text { participants with PD } \\
\text { divided into } \\
\text { Experimental group }(\mathrm{n}=24) \text { : home } \\
\text { physiotherapy programme focused } \\
\text { on chair transfers }(1 \text { hour } / 3 \\
\text { times/week, } 4 \text { weeks). } \\
\text { Control group ( } \mathrm{n}=23) \text { : Usual care. }\end{array}$ & $\begin{array}{l}\text { Main outcome measures: } \\
\text { Video-recorded (PAS; STS, SS- } \\
\text { 180, FR, Unified PD Rating Scale } \\
\quad \text { Posture Item. } \\
\text { Questionnaires: (SAS; HR-QOL). } \\
\text { The outcomes were taken at baseline, } \\
\text { before intervention (week } 0 \text { ), after } \\
\text { intervention (week 4) and at follow up } \\
\text { (week } 8 \text { and 12). }\end{array}$ & $\begin{array}{l}\text { 1. The results showed that both groups had been comparable } \\
\text { before the study. However, at the end of the treatment period, } \\
\text { the programme group showed a tendency for improvement in } \\
\text { all outcomes and the improvements were maintained } \\
\text { throughout the evaluation period. In contrast, the control } \\
\text { group showed a tendency for deterioration and this } \\
\text { deterioration was increased throughout the follow-up period. } \\
\text { Follow up: } \\
\text { 1- Median PAS score reaching } 7 \text { by week } 12 \text {. } \\
\text { 2- STS times continued shortening to week } 12 \\
\text { 3- Median SAS score tended to worsen in both groups by week } \\
\text { 12. } \\
\text { 4- Median SS-180 improved in the intervention group (3.8s). } \\
\text { 5- FR continued to improve in the intervention group (33\% } \\
\text { increase from baseline) while the control worsened. } \\
\text { 6- The median HR-QOLscore of intervention group had } \\
\text { returned to baseline while that of the control group was two } \\
\text { points worse. } \\
\text { Conclusion: a home- based physiotherapy programme consisting } \\
\text { of exercises and movement training strategies may have a positive } \\
\text { change in balance and functional mobility for people with PD. }\end{array}$ \\
\hline $\begin{array}{l}\text { Yi Yen et al (2011) } \\
\text { Taiwan }\end{array}$ & $\begin{array}{l}\text { To compare the effects of six } \\
\text { weeks of traditional balance } \\
\text { exercises, virtual reality- } \\
\text { augmented balance training, } \\
\text { and non-exercise control group } \\
\text { on postural stability in } \\
\text { individuals with PD. }\end{array}$ & $\begin{array}{l}\text { RCT } \\
42 \text { PD patients were consequently } \\
\text { randomized into three groups: } \\
\text { Group } 1(\mathrm{n}=14) \text { : The virtual reality } \\
\text { balance group (VR) trained on a } \\
\text { virtual reality balance system for } \\
\text { half an hour twice a week over six } \\
\text { weeks }\end{array}$ & $\begin{array}{l}\text { Main outcome measures: } \\
\text { The equilibrium scores at the } 6 \text { condition } \\
\text { of the SOT (SOT- } 1 \text { to SOR- } 6 \text { ). }\end{array}$ & $\begin{array}{l}\text { A significant improvement was noticed in terms of SOT-6 } \\
\text { score in VR group as compared to the control group } \\
(\mathrm{P}=0.001) \text {. } \\
\text { 2- In terms of the equilibrium score of SOT-5, a significant } \\
\text { improvement was noticed in CB group as compared to the } \\
\text { control group }(\mathrm{P}=0.001) \text {. } \\
\text { Conclusion: Both virtual reality and traditional balance exercise } \\
\text { were beneficial to address balance, since both groups showed }\end{array}$ \\
\hline
\end{tabular}




\begin{tabular}{|c|c|c|c|c|}
\hline & & $\begin{array}{l}\text { Group } 2(\mathrm{n}=14) \text { : The conventional } \\
\text { balance group }(\mathrm{CB}) \text { received a } \\
\text { thirty minute-session twice a week } \\
\text { for six weeks of balance exercises. } \\
\text { Control group }(\mathrm{n}=14) \text { : did not have } \\
\text { any type of exercise. }\end{array}$ & & significant improvement as compared to the control group. \\
\hline $\begin{array}{l}\text { Chaiwanichsiri, D. et al., } \\
\text { (2011) } \\
\text { Thailand }\end{array}$ & $\begin{array}{l}\text { Evaluate the effectiveness of } \\
\text { music cue on treadmill training } \\
\text { with idiopathic Parkinson's } \\
\text { disease. }\end{array}$ & 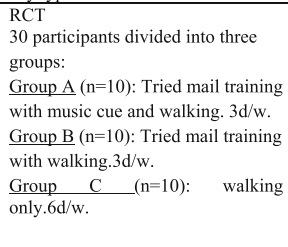 & $\begin{array}{l}\text { Main outcome measures: } \\
\text { - } \quad \text { Fall(s) within the past six months. } \\
\text { Gait and balance performance: } \\
\text { (TUG. ETUG, SLST, 6-MWT). } \\
\text { Step length and stride length. } \\
\text { Walking speed } \\
\text { The oudence. } \\
\text { three times at the begires were assessed } \\
\text { four week of training program and after } \\
\text { the end of eighth week. }\end{array}$ & $\begin{array}{l}\text { 1- The results showed that stride length }(\mathrm{P}=0.042) \text {, step } \\
\text { length }(\mathrm{P}=0.037) \text { and the six-minute walking test time } \\
(\mathrm{P}=0.001) \text { improved more in the treadmill with cueing } \\
\text { group, than in any other. } \\
\text { TUG test improved in group A and B more than } \mathrm{C} \text { at } 4^{\text {th }} \text { week } \\
(\mathrm{P}=0.039) \text {. } \\
\text { Conclusion: Application of music cueing may increase the benefit } \\
\text { of the treadmill training in PD patients. . }\end{array}$ \\
\hline
\end{tabular}
PD: Parkinson's disease; RCT: Randomized controlled trial; CB: Conventional balance training; PAS: Parkinson's activity scale; SS-180: Standing start 180 degree test; FR: Functional research; SAS: Self assessed
disability scale; SOT(SOT-1 to SOR-6): Sensory organization test' HR-QOL: Quality of life; STS: Sit-to-stand; VR: Virtual-reality; SLST: Single-leg-stance test; TUG: Timed up and go; ETUG: Expanded timed Up and Go test.

Table 2: Studies reported indirect effects of physiotherapy on fall(cont.).

\begin{tabular}{|c|c|c|c|c|}
\hline Author/Year/location & Aim & Method & Outcome measures & Result \\
\hline $\begin{array}{l}\text { Reuter,I.et al.,(2011) } \\
\text { Germany }\end{array}$ & $\begin{array}{l}\text { To examine the effects of } \\
\text { two different over-ground } \\
\text { walking programmes and } \\
\text { traditional physiotherapy } \\
\text { exercises. }\end{array}$ & $\begin{array}{l}\text { RCT } \\
90 \text { PD patients were allocated into three } \\
\text { groups and each group practised different } \\
\text { interventions: } \\
\text { Group1: Nordic walking (NW) training. } \\
\text { (attend three } 70 \text { minute sessions per week of } \\
\text { Nordic walking for six months) } \\
\text { 3times/w/6months. } \\
\text { Group2: walking training } 3 \text { times } / \mathrm{w} / 6 \text { months. } \\
\text { Group3: flexibility exercises and a relaxation } \\
\text { training } \\
\text { Three } 70 \text { minute sessions per week for six } \\
\text { months. }\end{array}$ & $\begin{array}{l}\text { Primary outcome: } \\
\text { Gait speed and gait parameters as } \\
\text { assessed using a treadmill } \\
\text { ergometer and } 12 \text { metre and } 24 \\
\text { metre walking tests. } \\
\text { UPDRS, } \\
\text { PDQ39. } \\
\text { Secondary outcome: } \\
\text { The secondary outcomes were } \\
\text { static and dynamic balance, as } \\
\text { measured by the Berg Balance } \\
\text { Test and the balance Pull Test } \\
\text { respectively. } \\
\text { Outcome measures were utilized before } \\
\text { and at the end of the programme }\end{array}$ & $\begin{array}{l}\text { 1. The results of the study showed that, compared to the } \\
\text { baseline assessment, all groups gained significant } \\
\text { improvements in terms of balance. However, only the } \\
\text { walking and Nordic walking groups gained significant } \\
\text { improvements in terms of gait velocity, stride length } \\
\text { and double stance as compared to the baseline. These } \\
\text { improvements were also significant when compared to } \\
\text { the traditional physiotherapy group. } \\
\text { 2. The results revealed that the Nordic walking group } \\
\text { improved more than the walking group in all } \\
\text { outcomes. } \\
\text { Conclusion: the authors concluded that all programmes are } \\
\text { beneficial to improve balance. However, only the walking } \\
\text { programmes are beneficial to improve gait velocity and gait } \\
\text { patterns. }\end{array}$ \\
\hline $\begin{array}{l}\text { Ebersbach et al., (2010) } \\
\text { Germany }\end{array}$ & $\begin{array}{l}\text { To compare the effects of } \\
\text { four weeks of a one-to-one } \\
\text { high-amplitude movement } \\
\text { programme (LSVT BIG), }\end{array}$ & $\begin{array}{l}\text { RCT } \\
\text { Sixty patients with PD were randomly divided } \\
\text { across these groups: } \\
\text { Group 1: one-to-one training (LSVT BIG), }(4\end{array}$ & $\begin{array}{l}\text { Primary outcome: } \\
\text { Secondary outcomes: }\end{array}$ & $\begin{array}{l}\text { 1. The results indicated that all groups showed } \\
\text { statistically significant improvements in all outcome } \\
\text { measures as compared to the baseline. However, } \\
\text { people in the LSVT BIG improved better than those in }\end{array}$ \\
\hline
\end{tabular}

\begin{tabular}{|c|c|c|c|c|}
\hline & $\begin{array}{l}\text { Nordic walking programme, } \\
\text { and unassisted home } \\
\text { exercises }\end{array}$ & $\begin{array}{l}\text { sessions/week/over } 4 \text { weeks) } \\
\text { Group 2: training of Nordic Walking } \\
\text { (WALK), ( } 2 \text { sessions/week/ for } 8 \text { weeks) } \\
\text { Group 3: domestic non-supervised exercises } \\
\text { (HOME) (1 session/ } 60 \text { minutes). }\end{array}$ & $\begin{array}{l}\text { PDQ-39. } \\
\quad \text { TUG. } \\
\text { Time to walk } 10 \mathrm{~m} \text {. } \\
\text { Outcome measures were applied both } \\
\text { before the study and at week sixteen } \\
\text { (follow up). }\end{array}$ & $\begin{array}{l}\text { the Nordic walking or home group in terms of } \\
\text { UPDRS-motor scale ( } \mathrm{P}=0.001) \text {, TUG }(\mathrm{P}=0.033) \text { and } \\
10 \mathrm{~m} \text { walking. } \\
\text { There were no significant group differences for } \\
\text { PDQ39 } \\
\text { Conclusion: The study showed that LSVT1BIG is an } \\
\text { effective technique to improve motor performance in } \\
\text { patients with PD. }\end{array}$ \\
\hline $\begin{array}{l}\text { Allen et al (2010) } \\
\text { Australia }\end{array}$ & $\begin{array}{l}\text { To examine the effects on } \\
\text { near fall incidence and fall } \\
\text { risk factors of a semi- } \\
\text { supervised exercise } \\
\text { programme containing a } \\
\text { cueing component in people } \\
\text { with PD. }\end{array}$ & $\begin{array}{l}\text { RCT } \\
48 \text { participants with Parkinson's disease (PD) } \\
\text { were randomised into : } \\
\text { Intervention group ( } \mathrm{n}=24) \text { ): progressive balance } \\
\text { and strengthening exercise } \\
\text { Control group(n=24): usual care. } \\
\text { (3times/week/6months). }\end{array}$ & $\begin{array}{l}\text { Primary outcome measure: } \\
\text { Secondary outcome measures: } \\
\text { SD falls isk score } \\
\text { - } \quad \text { FBS. } \\
\text { FOG questionnaire. } \\
\quad \text { Physical ability: the short physical } \\
\quad \text { performance battery (SPPB) } \\
\quad \text { (balance standing; sit to stand } \\
\quad \text { time; walking velocity). } \\
\text { - } \quad \text { FES-I questionnaire.PDQ-39. }\end{array}$ & $\begin{array}{l}\text { T- The results showed that the intervention group } \\
\text { demonstrated a better improvement in all outcomes. } \\
\text { The only significant between-group differences were } \\
\text { noted in terms of near fall incidence, } \mathrm{FOG}(\mathrm{P}=0.03) \\
\text { and the sit-to-stand task }(\mathrm{P}=0.03) \text {. } \\
\text { Conclusion: Exercise program for } \mathrm{PD} \text { who had a history of } \\
\text { recurrent falls or who had been classified as being at high } \\
\text { risk of falls may reduce overall risk of falling and can } \\
\text { improve FOG, sit-to-stand, and muscle strength. }\end{array}$ \\
\hline $\begin{array}{l}\text { Sage and Almeida (2009) } \\
\text { Canada }\end{array}$ & $\begin{array}{l}\text { To compare the effects of } \\
\text { movement strategies training } \\
\text { (PD SAFEx), aerobic } \\
\text { programmes and a control } \\
\text { group. }\end{array}$ & $\begin{array}{l}\text { RCT } \\
53 \text { participants with PD randomly allocated } \\
\text { into: } \\
\text { Intervention group ( } \mathrm{n}=18) \text { : PD SAFEx } \\
\text { training programme. This programme was } \\
\text { delivered via a group-sitting approach, three } \\
\text { times a week, over a ten to twelve week period } \\
\text { Aerobic group }(\mathrm{n}=13) \text { : lower limb aerobic } \\
\text { programme.. Thirty-six classes over a period of } \\
\text { twelve weeks } \\
\text { Control group }(\mathrm{n}=15) \text { : non-exercising. }\end{array}$ & $\begin{array}{l}\text { Main outcome measures: } \\
\text { - } \quad \text { UPDRS } \\
\text { TUG. } \\
\text { Spatiotemporal aspects of self- } \\
\quad \text { paced gait. } \\
\text { Outcomes were evaluated before(pre- } \\
\text { test) and at the end of the study(post- } \\
\text { test).. }\end{array}$ & 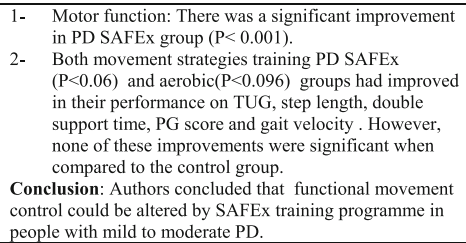 \\
\hline
\end{tabular}
PD: Parkinson's disease; RCT: Randomized controlled tri

Table 2: Studies reported indirect effects of physiotherapy on fall(cont.).

\begin{tabular}{|c|c|c|c|c|}
\hline Author/Year/location & Aim & Method & Outcome measures & Result \\
\hline $\begin{array}{l}\text { Hackney and Earhart (2009) } \\
\text { USA }\end{array}$ & $\begin{array}{l}\text { To compare the benefits of } \\
\text { thirteen weeks of tango } \\
\text { and (waltz/foxtrot) } \\
\text { interventions and no } \\
\text { physiotherapy treatment on } \\
\text { functional motor control in } \\
\text { people with PD. }\end{array}$ & $\begin{array}{l}58 \text { people with PD were subsequently } \\
\text { randomly allocated into the three groups } \\
\text { Group1 }(\mathrm{n}=14) \text { tango, } \\
\text { Group } 2(\mathrm{n}=17) \text { waltz/foxtrot or } \\
\text { Group3 ( } \mathrm{n}=17 \text { ) no intervention "control } \\
\text { group". } \\
\text { People in the tango and waltz/foxtrot } \\
\text { groups attended twenty classes over }\end{array}$ & $\begin{array}{l}\text { Main outcome measures: } \\
\quad \text { UPDRS. } \\
\text { BBS. } \\
\text { TUG. } \\
\text { 6MWT. } \\
\text { All assessment measures were } \\
\text { videotaped a week before and after }\end{array}$ & $\begin{array}{l}\text { After completion of } 20 \text { training sessions: } \\
\text { 1- The results revealed that although all groups had been comparable } \\
\text { at the pre-study tests, both tango and waltz/foxtrot groups had } \\
\text { improved more than the control group in all outcomes. } \\
\text { 2- Compared to the control group, both tango and waltz/foxtrot } \\
\text { groups had significant improvements in balance, gait endurance } \\
\text { and backward stride length. } \\
\text { 3- With regard to FOG and the TUG tests, only the tango group had }\end{array}$ \\
\hline
\end{tabular}




\begin{tabular}{|c|c|c|c|c|}
\hline & & $\begin{array}{l}\text { thirteen weeks, while people in the control } \\
\text { group received only pre- and post-study } \\
\text { assessments. }\end{array}$ & the study. & $\begin{array}{l}\text { improved statistically. } \\
\text { Conclusion: Tango and waltz/foxtrot may benefit in fall risk factors in } \\
\text { PD. }\end{array}$ \\
\hline $\begin{array}{l}\text { Frazzitta et al., (2009) } \\
\text { Italy }\end{array}$ & $\begin{array}{l}\text { To compare the effects of } \\
\text { treadmill training in } \\
\text { association with visual and } \\
\text { auditory cues and } \\
\text { traditional over-ground } \\
\text { gait training programmes. }\end{array}$ & $\begin{array}{l}\text { RCT } \\
40 \text { Parkinson's patients were randomly } \\
\text { and equally divided into: } \\
\text { Group1 }(\mathbf{n}=\mathbf{2 0}): \text { Twenty minutes of } \\
\text { treadmill training associated with auditory } \\
\text { and visual cues over four weeks on a daily } \\
\text { basis } \\
\text { Group2 ( } \mathbf{n}=\mathbf{2 0}) \text { : Over-ground gait } \\
\text { training for the same duration using only } \\
\text { auditory and visual cues. }\end{array}$ & $\begin{array}{l}\text { Main outcome measures: } \\
\text { - } \quad \text { UDRS. } \\
\text { FOGQ } \\
\text { 6MWT. } \\
\text { Gait speed } \\
\text { All measurements were assessed } \\
\text { both before (baseline) and at the } \\
\text { end of study (post-treatment). }\end{array}$ & $\begin{array}{l}\text { Post-treatment: } \\
\text { Both groups had gained significant improvements in all areas. } \\
\text { However, the gains achieved after the treadmill training appeared to be } \\
\text { superior to those achieved after the over-ground training(all } \mathrm{P}=0.001) \text {. } \\
\text { Conclusion: treadmill training associated with visual and auditory cues } \\
\text { could be more effective than traditional rehabilitation with auditory and } \\
\text { visual cues alone. }\end{array}$ \\
\hline $\begin{array}{l}\text { Fisher et al (2008) } \\
\text { USA }\end{array}$ & $\begin{array}{l}\text { To compare the effects of } \\
\text { gait training on a partial } \\
\text { weight support treadmill } \\
\text { system and a conventional } \\
\text { physiotherapy programme } \\
\text { consisting of a wide range } \\
\text { of exercises for people } \\
\text { with PD }\end{array}$ & $\begin{array}{l}\text { RCT } \\
30 \text { PD patients were recruited and } \\
\text { randomized to three groups: } \\
\text { Group 1:( treadmill intervention): High } \\
\text { intensity exercise.(twenty-four sessions of } \\
\text { partial weight support treadmill training } \\
\text { over a period of two months). } \\
\text { Group 2(conventional exercises): Low } \\
\text { intensity exercise.( twenty-four sessions of } \\
\text { low intensity exercises over a period of } \\
\text { two months) } \\
\text { Group 3: Zero-intensity (no exercise) } \\
\text { group. } \\
24 \text { sessions over a period of two months. }\end{array}$ & $\begin{array}{l}\text { Main outcome measures: } \\
\text { - UPDRS. } \\
\text { - Walking test. } 10 \mathrm{~m} \text {. } \\
\text { STS test. } \\
\text { The effects of the programmes were } \\
\text { assessed at two different points, } \\
\text { both before randomization and } \\
\text { immediately after the end of the } \\
\text { study }\end{array}$ & $\begin{array}{l}\text { 1- The results showed that all groups gained slight improvements. } \\
\text { However, there were no significant pre-post programme changes } \\
\text { in all outcome measures across any of the groups. } \\
\text { 2- Some improvements have been recorded in the high intensity } \\
\text { exercise regarding self-selected gait speed ( } 4.4 \%) \text {, stride length } \\
\text { (4.7\%), step length }(5.8 \%) \text {, hip and ankle and lengthening in } \\
\text { CSP. } \\
\text { Conclusion: Intensive wide range of exercises may play an important } \\
\text { role in corticomotor excitability in early PD. }\end{array}$ \\
\hline $\begin{array}{l}\text { Morris et al., (2008) } \\
\text { Australia }\end{array}$ & $\begin{array}{l}\text { To compare movement } \\
\text { rehabilitation strategies } \\
\text { training and conventional } \\
\text { physiotherapy programmes } \\
\text { in hospitalized patients } \\
\text { with PD. }\end{array}$ & $\begin{array}{l}\text { RCT } \\
28 \text { PD patients were equally assigned to } \\
\text { either } \\
\text { Group } 1(n=14) \text { : movement strategy } \\
\text { training. } \\
\text { Group 2(n=14): Musculoskeletal } \\
\text { exercises. }\end{array}$ & $\begin{array}{l}\text { Main outcome measures: } \\
\text { De Disability (UPDRS). } \\
\text { Secondary outcomes: } \\
\text { Balance, walking speed, } \\
\quad \text { endurance and quality of life } \\
\text { (PDQ-39). } \\
\text { Assessments were conducted three } \\
\text { times, at baseline before the study, } \\
\text { at the end of the two weeks and } \\
\text { finally three months after the end of } \\
\text { the study. }\end{array}$ & $\begin{array}{l}\text { - The movement strategies group had gained significant } \\
\text { improvements in all outcome measures including UPDRS scores } \\
(\mathrm{P}=0.008) \text {, balance }(\mathrm{P}=0.002), 10 \text { meter walk }(\mathrm{P}=0.003) \text { and } \\
\mathrm{PDQ} 39 \text {. However, these improvements had declined by the three } \\
\text { month follow-up. } \\
\text { The conventional exercise group, did not show any significant } \\
\text { improvement. } \\
\text { The results indicated that two weeks of cognitive motor training } \\
\text { led to short-term benefits in terms of static balance, walking } \\
\text { velocity, walking endurance and disability level. } \\
\text { Conclusion: Movement strategy training led to short-term benefits in } \\
\text { terms of static balance, walking velocity, walking endurance and } \\
\text { disability level }\end{array}$ \\
\hline
\end{tabular}
questionnaire; 6MWT: 6-Minute walk test; PDQ-39: Parkinson's disease questionnaire; STS: sit-to-stand; FOGQ: Freezing of gait questionnaire . Table 2: Studies reported indirect effects of physiotherapy on fall(cont.).

\begin{tabular}{|c|c|c|c|c|}
\hline Author /Year/location & Aim & Method & Outcome measures & Result \\
\hline $\begin{array}{l}\text { Kurtais.et al.,(2008) } \\
\text { Turkey }\end{array}$ & $\begin{array}{l}\text { To investigate the effects of gait } \\
\text { training on the treadmill on } \\
\text { different functional tasks, gait } \\
\text { velocity and static balance in } \\
\text { patients PD. }\end{array}$ & $\begin{array}{l}\text { RCT } \\
30 \text { patients with PD were consequently } \\
\text { divided into either: } \\
\text { Intervention group }(\mathrm{n}=12) \text { : Treadmill } \\
\text { training. (3times/ } / 6 \text { weeks). } \\
\text { Control group }(\mathrm{n}=12) \text { : No intervention. }\end{array}$ & $\begin{array}{l}\text { Main outcome measures: } \\
\text { Functional tasks. } \\
\text { Assessments of patients were carried out } \\
\text { at baseline and at the end of treatment. }\end{array}$ & $\begin{array}{l}\text { Results showed that people in the treadmill group gained } \\
\text { significant improvement in in functional lower extremity } \\
\text { tests as compared to the control group. } \\
\text { Conclusion: Treadmill training in PD patients may } \\
\text { improve functional mobility and static balance. }\end{array}$ \\
\hline $\begin{array}{l}\text { Mak and Hui-Chan (2008). } \\
\text { China }\end{array}$ & $\begin{array}{l}\text { To examine the effects of a } \\
\text { movement strategies training } \\
\text { programme and traditional } \\
\text { physiotherapy intervention on an } \\
\text { important functional task, sit-to- } \\
\text { stand. }\end{array}$ & $\begin{array}{l}\text { RCT. } \\
60 \text { PD patients were randomly allocated } \\
\text { into:: } \\
\text { Group1 ( } \mathbf{n}=\mathbf{2 1}) \text { : receive AV cued task- } \\
\text { specific training (twenty minutes, three } \\
\text { times a week / for } 4 \text { weeks). } \\
\text { Group2 }(\mathbf{n}=\mathbf{2 1}) \text { : conventional exercise } \\
\text { (Ex), ( } 45 \mathrm{~min} / 2 \text { weeks/ for } 4 \text { weeks). } \\
\text { Control group ( } \mathbf{n}=\mathbf{1 8}) \text { : did not receive } \\
\text { any treatment }(4 \text { weeks). }\end{array}$ & $\begin{array}{l}\text { Main outcome measures: } \\
\text { Three dimensional kinematics data } \\
\text { of STS were recorded using a } \\
\text { VICON motion analysis system } \\
\text { with } 6 \text { cameras. } \\
\text { Measurements were carried out } \\
\text { before(week0), during (week2), at the end } \\
\text { of the study(week4) and two weeks after } \\
\text { the study }\end{array}$ & $\begin{array}{l}\text { The AV group significantly increased with the Ex. } \\
\text { Group. } \\
\text { Only the cueing and exercise groups gained } \\
\text { significant improvements in terms of sit-to-stand } \\
\text { time as compared to the baseline }(\mathrm{P}=0.01) \text {. These } \\
\text { improvements were also statistically significant } \\
\text { when compared with the control group. The } \\
\text { improvements were also maintained at two weeks } \\
\text { after the end of the study. } \\
\text { Conclusion: AV cued task-specific training may play an } \\
\text { important role in improving functional performance in } \\
\text { patients with PD. }\end{array}$ \\
\hline $\begin{array}{l}\text { Hackney et al. (2007) } \\
\text { USA }\end{array}$ & $\begin{array}{l}\text { To compare the effects of thirteen } \\
\text { weeks of two movement } \\
\text { programs: Argentine tango dance } \\
\text { lessons (tango) or a } \\
\text { strength/flexibility exercise } \\
\text { classes (exercise) on gait, } \\
\text { functional mobility and balance. }\end{array}$ & $\begin{array}{l}\text { RCT } \\
19 \text { PD patients were allocated randomly } \\
\text { to either: } \\
\text { Group } 1(\mathrm{n}=9) \text { : Tango. } \\
\text { Group2(n=10): Exercise. } \\
\text { I hour } / \text { week } / 20 \text { sessions/ for } 13 \text { weeks }\end{array}$ & $\begin{array}{l}\text { Main outcome measures: } \\
\text { UPDRS. } \\
\text { BBS. } \\
\text { Gait velocity: } 5 \text {-m walking. } \\
\text { TUG. } \\
\text { The performantionnaire on these scales was } \\
\text { recorded on a videotape both before and } \\
\text { after the intervention. }\end{array}$ & $\begin{array}{l}\text { The results showed that the people in the tai chi } \\
\text { group improved better than the control group in the } \\
\text { UPDRS ( } \mathrm{P}=0.001) ; \text { BBS }(\mathrm{P}=0.001) ; \text {, backward } \\
\text { walking velocity, gait stride and also in terms of gait } \\
\text { endurance. } \\
\text { Conclusion: Tai chi leads to positive benefits in terms of } \\
\text { gait, balance and functional mobility specific to PD. }\end{array}$ \\
\hline $\begin{array}{l}\text { Cakit et al., (2007) } \\
\text { Turkey }\end{array}$ & $\begin{array}{l}\text { Examined the effects eight weeks } \\
\text { of gait training on the treadmill } \\
\text { on postural instability, balance } \\
\text { and FOF with PD patient. }\end{array}$ & $\begin{array}{l}\text { RCT } \\
54 \text { with PD were equally separated into: } \\
\text { Experimental (treadmill training)group } \\
\text { (n=27): received speed dependent } \\
\text { treadmill training, combined with range } \\
\text { of motion and stretching exercises. } \\
\text { Control group ( } \mathrm{n}=27) \text { : did not receive } \\
\text { any training }\end{array}$ & $\begin{array}{l}\text { Main outcome measures: } \\
\text { - } \quad \text { Functional status: UPDRS. } \\
\text { Balance: BBS. } \\
\text { Dynamic gait index. } \\
\text { The palls efficacy scale. } \\
\text { before and at the end of the study. }\end{array}$ & $\begin{array}{l}\text { The result showed statistical significance for the outcomes } \\
\text { between the groups at baseline and eight weeks. The } \\
\text { intervention group had significant changes in walking } \\
\text { distance (from } 2.66 .45 \mathrm{~m} \text { to } 726.36 \mathrm{~m} \text { ) and tolerated } \\
\text { maximum speed on treadmill( }(1.9 \mathrm{~km} / \mathrm{h} \text { to } 2.61 \mathrm{~km} / \mathrm{h} \text { ), Berg } \\
\text { balance test, Dynamic Gait Index (P=0.01)and Falls } \\
\text { Efficacy Scale. } \\
\text { Conclusion: Treadmill programme had led to significant } \\
\text { improvement on mobility and FOF in patients with PD. }\end{array}$ \\
\hline $\begin{array}{l}\text { Schmitz-Hubsch et al (2006) } \\
\text { Germany }\end{array}$ & $\begin{array}{l}\text { To evaluate the immediate and } \\
\text { sustained effects of Qigong on } \\
\text { motor and non-motor symptoms } \\
\text { of PD. }\end{array}$ & $\begin{array}{l}56 \text { patients with PD distributed } \\
\text { randomly into: } \\
\text { Intervention group ( } \mathrm{n}=32) \text { : Two courses } \\
\text { of Qigong exercise ( } 60 \text { minutes } / 8 \text { weeks } \\
\text { with } 8 \text { week pause in between). } \\
\text { Control group }(\mathrm{n}=24) \text { : Usual care } \\
\end{array}$ & $\begin{array}{l}\text { Main outcome measures: } \\
\quad \text { UPDRS-III. } \\
\quad \text { PDQ-39. } \\
\quad \text { Quality of life. } \\
\text { Measurements were repeated at four }\end{array}$ & 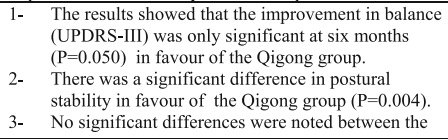 \\
\hline
\end{tabular}




\begin{tabular}{|c|c|c|c|c|}
\hline & & & $\begin{array}{l}\text { different points: at baseline, at three } \\
\text { months, at six months and after one year. }\end{array}$ & $\begin{array}{l}\text { two groups in terms of PDQ-39. } \\
\text { 4- Score in MARDS for depressive symptoms } \\
\text { decreased in both groups. } \\
\text { Conclusion: Qigong is a promising treatment with } \\
\text { possible effects on motor as well as non-motor symptoms } \\
\text { with PD. }\end{array}$ \\
\hline \multicolumn{5}{|c|}{$\begin{array}{l}\text { PD: Parkinson's disease; RCT: Randomized controlled trial; UPDRS: Unified Parkinson's disease rating scale; PDQ-39: Parkinson's disease questionnaire ; AV audio-visual; STS: sit-to-stand; BBS: Berg Balance } \\
\text { Scale; TUG: Timed Up and Go; FOG: Freezing of gait; UPDRS-III: The unified Parkinson's disease rating scale motor part; MADRS : The Montgomery -asperg depression rating scale. } \\
\text { Table 2: Studies reported indirect effects of physiotherapy on fall(cont.). }\end{array}$} \\
\hline Author/Year/location & Aim & Method & Outcome measures & \begin{tabular}{l|l} 
Result \\
\end{tabular} \\
\hline $\begin{array}{l}\text { Hirsch et al., (2003) } \\
\text { USA }\end{array}$ & $\begin{array}{l}\text { To compare the effects of ten weeks } \\
\text { of a programme consisting of a } \\
\text { combination of balance and } \\
\text { resistance training with a control } \\
\text { group who received balance } \\
\text { training only on PD. }\end{array}$ & $\begin{array}{l}\text { RCT } \\
\text { A total of } 15 \text { participants with PD divided into: } \\
\text { Group } 1(\mathbf{n}=\mathbf{6}) \text { : received resistance training } \\
\text { and balance training exercises (combined } \\
\text { group).. } \\
\text { Group } 2 \text { ( }(\mathrm{n}=\mathbf{9}) \text { : received balance training } \\
\text { only. } \\
\text { People in the balance group received half an } \\
\text { hour of balance exercises, three times a week } \\
\text { for ten weeks, while the combined group } \\
\text { received fifteen minutes progressive resistance } \\
\text { exercise in addition to thirty minutes of } \\
\text { balance exercises. }\end{array}$ & $\begin{array}{l}\text { Main outcome measures: } \\
\text { - Balance: SOT. } \\
\text { Muscle strength. } \\
\text { All measurements were obtained ay } \\
\text { baseline, post-treatment (with } 5 \text { days of } \\
\text { completion of training) and follow up. }\end{array}$ & $\begin{array}{l}\text { 1- It appeared that the combination of balance and } \\
\text { resistance exercise led to more benefits in terms } \\
\text { of balance and muscle strength and these were } \\
\text { statistically significant. } \\
\text { 2- Four weeks after the training ended, the mean } \\
\text { for the balance group declined to near pre- } \\
\text { treatment level, whereas scores for the } \\
\text { combined group declined moderately. } \\
\text { Conclusion: Both interventions are beneficial but, } \\
\text { combining balance with strengthening exercise is } \\
\text { more beneficial may reduce fall risk for people with } \\
\text { PD. }\end{array}$ \\
\hline $\begin{array}{l}\text { Pohl et al (2003) } \\
\text { Germany }\end{array}$ & $\begin{array}{l}\text { To explore the immediate effects of } \\
\text { thirty minutes of different gait } \\
\text { training techniques on gait } \\
\text { parameters in patients with early } \\
\text { PD. }\end{array}$ & $\begin{array}{l}\text { RCT } \\
17 \text { PD patients were assigned randomly either: } \\
\text { Group 1: Structured speed dependent treadmill } \\
\text { (STT). } \\
\text { Group 2: Limited progressive treadmill.(LTT). } \\
\text { Group 3: Over-ground traditional gait } \\
\text { training(CGT), and } \\
\text { Control group. }\end{array}$ & $\begin{array}{l}\text { Main outcome measures: } \\
\text { Walking velocity. } \\
\text { stride length. }\end{array}$ & $\begin{array}{l}\text { 1. The results showed that training on both } \\
\text { treadmill interventions had led to significant } \\
\text { improvements }(\mathrm{P}=0.01) \text { compared to the pre- } \\
\text { training tests and both control and over-ground } \\
\text { gait training interventions. } \\
\text { Conclusion: The authors concluded that gait } \\
\text { disturbance in people with PD could be altered by } \\
\text { only one session of treadmill training (STT) or LTT, } \\
\text { but not through CGT and the control group. }\end{array}$ \\
\hline $\begin{array}{l}\text { Muller et al., (1997) } \\
\text { Germany }\end{array}$ & $\begin{array}{l}\text { To compare the effects of ten weeks } \\
\text { of a programme that used different } \\
\text { movement training strategies, } \\
\text { targeting different functional tasks, } \\
\text { with a control intervention on } \\
\text { postural and gait initiation in } \\
\text { Parkinson's disease. }\end{array}$ & $\begin{array}{l}\text { RCT } \\
29 \text { patients with PD randomly distributed into: } \\
\text { Experimental group }(\mathrm{n}=15) \text { : specific } \\
\text { strategies(such as cueing, dividing complex } \\
\text { tasks and aiming at improving different } \\
\text { functional tasks.). } \\
\text { Control group ( } \mathrm{n}=14 \text { ): non-specific treatment } \\
\text { (information about disease and breathing } \\
\text { exercise). } \\
\text { Both groups received a session of an hour and } \\
\text { a half every week. }\end{array}$ & $\begin{array}{l}\text { Main outcome measures: } \\
\text { - UPDRS. } \\
\text { Modified Hoehn and Yahr Scale. } \\
\text { Beck depression Inventory. }\end{array}$ & $\begin{array}{l}\text { 1. The result showed that statistically significance } \\
\text { between group differences were observed in } \\
\text { beck depression inventory, mentation, behavior } \\
\text { and mood. } \\
\text { 2. The intervention group gained significant } \\
\text { improvements in balance as compared to the } \\
\text { control group. } \\
\text { 3. The motor examination, activities of daily } \\
\text { living, and Hoehn and Yahr Scale showed a } \\
\text { significance improvement pre-post treatment } \\
\text { only in the intervention group. forward }\end{array}$ \\
\hline
\end{tabular}

\begin{tabular}{|l|l|l|l|l|}
\hline & & & $\begin{array}{l}\text { bending during walking showed a significance } \\
\text { decline in the control group. The time to onset } \\
\text { of arm flexion demonstrate a significant in the } \\
\text { intervention group compared with control } \\
\text { group. } \\
\text { Conclusion: Behavioral } \\
\text { improve motor disability } \\
\text { PD patients. }\end{array}$ & \\
in moderately advanced & & \\
\hline
\end{tabular}
D: Parkinson's disease; RCT: Randomized controlled
treadmill; CGT: Over-ground traditional gait training

studies did not report significant effects [35, 38, 41]. One of the three studies that did not report a remarkable difference between-group used exercise in the comparison intervention [38]. However, this study reported a significant difference as compared to the baseline data within the same group. The second study [41] compared the effects of physiotherapy intervention to a control and found a trend towards improvement in the intervention group, while the control group showed a tendency for deterioration. The third study, by Hackney et al. [35], compared the effects of tango dance or strength/flexibility exercise. The study also reported that balance may be a beneficial to address balance and gait problems specific to PD.

\section{Effects of functional mobility/performance on func- tional task}

Various studies have analyzed the impact of physiotherapy on functional performance. In this paper, seven studies were reliable in giving the outcomes that physiotherapy interventions lead to a significant improvement in performance on functional task measures as timed up and go (TUG) test, sit-to-stand test, and climbing stairs [34, 37, 38, 41, 45-47]. In light of the after effects of these trials, it gives the idea that physiotherapy is advantageous as far as enhancing functional mobility. However, different physiotherapy programs and different durations were used in these studies. This makes it hard to propose the best kind of physiotherapy to address this issue.

A few authors have contended that, notwithstanding, the motor symptoms associated with PD sufferers are still typically ready to perform complex movements in specific circumstances [36].

Therefore, they suggest using movement strategies training to compensate for and bypass the deficits in the basal ganglia. Three studies used movement strategies training either as a stand-alone intervention or combined with other exercise, and each showed positive results $[38,44,46]$. However, other studies examined the effects of programs that do not include movement strategies and showed positive results [34, 37]. These programs include tango or treadmill. Thus, it makes it difficult to pinpoint which type of physiotherapy is more effective. 


\section{Effect on gait/muscle strength}

Fifteen studies included in this part of scoping review reported outcomes related to gait deficits and showed promising results [29, 34-40, 42, 46-51]. The most result measure used to assess gait quality in these studies is gait velocity over a short distance. Ten of which indicated significant enhancement on account of the physiotherapy [29, 34, 36-38, 40, 42, 47, 48, 51]. Other gait results, for example, stride length and walking endurance, were additionally assessed in a few studies and were found to enhance with physiotherapy [34, 36, 48, 49].

Findings emerging from the results of the reviewed studies, related to gait and fall risk, are that people suffering from fear of gait (FOG) are likely to benefit from physiotherapy. However, this finding rises out of a predetermined number of studies.

Just six trials provided details regarding gait freezing [34-36, 40, 44, 48]. Three out of the six trials demonstrated positive results for physiotherapy when contrasted either with control or with some other active intervention [40, 44, 48]. The lack of significant improvements in the other three studies does not necessarily indicate the absence of the benefits of physiotherapy. To illustrate, all of these studies did not target FOG specifically and did not include such a problem as an inclusion or exclusion criterion.

\section{Effect of muscle strength}

It appears that muscle strength may likewise enhance after physiotherapy in individuals with PD [44]. Hirsch et al. [31] compared the benefits of two physiotherapy interventions on two fall risk factors, namely balance and muscle strength. In this study, Hirsch et al. [31] compared the effects of 10 weeks of a program consisting of a combination of balance and resistance training with a control group who received balance training only. The results of this study were promising and showed that both groups gained significant improvements in all outcomes, and these gains were maintained for at least 4 weeks. However, the program of this study mainly focused on muscle strength, whereas strengthening training, in another study, represents a small portion of the programs. For example, Allen et al. [44] used resistance training as a component of a program that included cueing strategies and balance training. Therefore, it might be argued that the dose of the strengthening exercise was not sufficient enough to produce change in muscle power.

\section{Discussion}

\section{Direct impact of physiotherapy interventions on fall}

Even though falling is predominant among those experiencing PD, little work has been done to prevent this issue. Only 15 studies examined the direct effect of physiotherapy in fall in this specific population. The sample size was small in most of the inspected studies. Besides, the subsequent periods in the included studies were moderately short, with most of the studies looking at the impacts of physiotherapy immediately after the end of the interventions.

However, this paper represents the accessible studies that inspect the advantages of physiotherapy for individuals with PD. The immediate effects of physiotherapy in fall were estimated in these studies in terms of fall number and near fall incidence. These results were gathered fundamentally utilizing a self-reported fall diary sheet that was finished by participants themselves or medical staff. However, although fall diaries are considered valid and a reliable way to record fall incidence, factors such as participants' ability to recall fall incidence, education level, and native language may affect the accuracy of the recording of fall in such diaries, and this should be considered when using this approach [52]. Despite this, the consequences of this scoping review propose that physiotherapy intervention may be useful in decreasing the quantity of falls and near fall incidence in individuals experiencing PD [15-17, 20, 21, 23, 25, 26]. This suggestion is based on limited evidence. Eleven studies showed that physiotherapy resulted in a reduction of fall rate $[14,15$, 17-21, 23, 24, 26]. Yet, this reduction was significant only in seven studies $[4,15,18,20,23,24,26]$. Also, one study reported near fall incidence as outcomes and showed significant reduction [21]. The absence of the significant decrease in the number of falls in this study does not really demonstrate the absence of the impacts of physiotherapy. Rather, it may indicate the lack of adequate sample size to detect this change statistically, as noticed in the studies conducted by Protas et al. [14] and Martin et al. [25]. Another conceivable explanation behind the absence of significant improvement in terms of fall rates is the absence of incorporating appropriate intensity and type of training. Observably, every one of the interventions that did not reveal remarkable improvement involved interventions of moderately brief length or exercises that did not challenge balance, while the proof rising up out of studies concerning the older population in general recommend a higher dose of exercise and activities that challenge balance to achieve a positive impact on fall rate $[5,44]$. Sherrington et al. [5] conducted a systematic review and meta-analysis and indicated that approximately half of the fall incidence among old people can be prevented by a well-designed program with a dose of at least $50 \mathrm{~h}$ over the trial period. Additionally, they brought up that intervention, including exercise, that challenges balance capacities are bound to counteract fall more often than those intervention comprising of different sorts of activities, for example, walking or strengthening exercises.

Therefore, it is not surprising when a significant reduction in fall number was noticed in the studies $[20,26,27]$ that 
incorporated a tai chi exercise program with a high dose $(1 \mathrm{~h}$, twice weekly for 6 months, $>50 \mathrm{~h}$ ). The tai chi exercise is also considered a balance-based exercise.

Similarly, Smania et al. [26] used a variety of exercises that greatly challenge balance in different situations including standing, walking, and when doing functional activities, and a significant reduction in fall numbers was demonstrated. However, the dose of this program was $1 \mathrm{~h}$ twice weekly for 7 weeks, which was lower than the recommended dose $(<50$ h). Thus, it might be argued that interventions consisting of only balance exercises that exceptionally challenge postural control in various circumstances may be a decent system to prevent fall in individuals with $\mathrm{PD}$, even with the portion lower than the suggested dimension. However, this needs further examination. Another related finding is that programs, for the most part contain and fortify preparation, appear to be not viable in terms of fall rate decreasing in individuals with PD. Some included studies exploring the advantages of a strengthening exercise program and demonstrated that the strengthening activity had not caused any significant decrease in fall occurrence in correlation with the control group [20, 24, 25].

It is consistent with several systematic reviews concerning fall in general in older people. For example, Sherrington et al. [5] conducted a systematic review of 44 controlled randomized trials and showed that strengthening exercise alone is not beneficial for old people who suffer from recurrent falls. Other review has been conducted by Shen et al. [11] who showed that no clear evidence that training exercise decreased the number of fallers in PD over the short- or long term.

In addition, due to the limited number of trials reviewed in this paper which report the direct impact of physiotherapy on fall, these findings should be interpreted with caution. Furthermore, more control randomized trials with large sample sizes are required both to affirm these discoveries as well as to locate the intensity and type of exercise. Additionally, it should be clarified that all these trials included individuals with PD who did not have other neurological conditions and who were mentally and medically stable. In this way, generalization of these findings to other populations is not advisable.

\section{Indirect effects of physiotherapy on fall effect on composite score}

Recruiting many people can prove difficult to achieve, especially when researchers target a specific population such as people with PD [44]. For this situation, composite score is a decent technique to be used [44]. Composite score can be utilized to demonstrate the risk of falling, and the consequence of the reviewed trials shows that physiotherapy may positively affect such a measure. In this paper, two studies used a composite score (PIGD) that includes items related to gait and balance $[22,46]$. These two studies exhibited that physiotherapy interventions lead to significant positive effects on such a score, when contrasted with usual care. Nonetheless, there is no one study that examined the sensitivity of this measure to foresee future fall. Then again, one study focused on fallers utilizing a composite score, PD fall risk score, that incorporates commitment that includes weight from muscle strength, balance, and FOG [44]. The authors in this study cited the validity and reliability of this measure. However, they found that physiotherapy did not result in any significant improvement in this score when compared to usual care.

\section{Effect on balance}

Considering the consequences of the studies included in this paper, it appears that different types of physiotherapy can possibly enhance balance. These types include traditional balance training, virtual reality balance training, resistance exercise, tai chi, movement training strategies, treadmill training, and multi-dimensional interventions. In any case, because of the various number of measures utilized, and the limited number of studies that analyze the impacts of various physiotherapy intervention on balance, it is not clear what sort of physiotherapy is the most beneficial for balance. A systematic review conducted by Addison et al. [53] contend that the type of physical activity may lead to an improvement in balance performance. Although this discovery supports the use of physiotherapy, the degree of the advantages is not known. Accordingly, future studies should address this impediment and focus on identifying the best intervention to target balance impairment in people with PD.

\section{Effects on functional mobility/performance on func- tional tasks}

Difficulty in performing functional tasks is one of the problems associated with PD and is strongly associated with fall. Measures intended to assess functional performance can be utilized to assess either balance or fall risk in individuals with PD. Consequently, various studies $[4,19,20,26,29,34,37$, 45] have analyzed the impact of physiotherapy on such results. In view of the results of these trials, it gives the idea that physiotherapy is advantageous regarding enhancing functional mobility. However, distinctive physiotherapy programs and diverse duration were utilized in these studies. This makes it hard to propose the best kind of physiotherapy to address this issue.

\section{Effects on gait}

Abnormal gait is, with no uncertainty, one of the elements that is unequivocally connected with fall and balance in individuals with PD. In this paper, distinctive interventions related to 
gait deficits were utilized in the included studies and showed promising results. These interventions were various, going from movement strategies training to daily walking at home. Therefore, extracting a message about the best method to improve gait speed, stride, and endurance is difficult. Be that as it may, it creates the impression that interventions involving walking exercise or movement strategy training are more valuable than those without [36, 51]. Additionally, the results of the reviewed studies suggest that treadmill training, nordic walking, and amplitude movement training are better than traditional over-ground gait training [38, 46, 48]. However, these recommendations depend on a set number of studies and need further investigation.

\section{Effects on muscle strength}

Lower limb muscle strength is an important fall risk factor. It has been found that there is a strong relationship between lower extremities' muscle strength and fall risk in people with PD [15]. This is normal because these muscles play a role in maintaining static and balance in people [44]. Moreover, there is a connection between muscle strength and gait patterns and walking ability which are also considered fall risk factors in people with PD [50]. In view of the consequences of the studies incorporated into this paper, it appears that muscle strength may likewise enhance after physiotherapy in individuals with PD [4, 16, 20, 28, 31]. In any case, it ought to be viewed that the aftereffects of the included studies were conflicting and future examinations may change this case. To illustrate, four studies reported on muscle strength, two of which found significant improvement as compared to either no physiotherapy treatment or an active intervention [20,31], while two studies did not find significant gains [21, 44]. These studies had programs containing resistance training. Nonetheless, intensity was different among the trials. The studies that showed critical enhancement had programs mainly focusing on muscle strength, while strengthening training, in alternate studies, represents a small portion of the programs. Consequently, the effect of physiotherapy on muscle strength should be further investigated.

\section{Effects of physiotherapy on FOF}

Fear of falling, or FOF, is additionally one of the fundamental contributing elements to the beginning of fall in individuals with $\mathrm{PD}$, and the discoveries of this paper support the use of physiotherapy to target the fear of falling. Four studies analyzed the effect of physiotherapy intervention on this fear, and these studies demonstrated critical positive outcomes for physiotherapy $[19,22,26$, 33]. Distinctive interventions were utilized in these studies, including cueing training, balance exercise, and treadmill training. Detectably, every one of the trials revealed enhancement in fear of falling and furthermore indicated enhancement in balance. This may show that impaired balance is a fundamental driver for the beginning of the fear of falling, and along these lines, any enhancement as far as balance would prompt a lessening in this fear. In this way, it tends to be contended that any intervention is gainful because of a paranoid fear of falling if it enhances balance. This finding is like the evidence emerging from systematic reviews that concern the effects of physiotherapy on elders in general. For instance, Zijlstra et al. [54] reviewed 11 controlled randomized trials and indicated that different kinds of exercise programs, such as tai chi exercise and balance training, have the potential to improve the fear of falling in elderly people living in the community, although these studies were not planned explicitly to treat the fear of falling.

\section{Conclusion}

Falling is one of the complications related with PD that effects up to $83 \%$ of sufferers. It creates the impression that this issue is likewise repetitive. Subsequently, a generous number of studies have been led to distinguish the factors that contribute to the onset of fall in this population and consequently several factors have been illustrated. These factors include previous fall history, impaired balance, gait problems, muscle weakness, and poor performance in functional activities, depression, and FOF. However, little work has been done in terms of fall prevention. The result of this study is promising. In any case, it appears that few controlled randomized trials have not been done to examine the direct impacts of physiotherapy on fall. Despite this, there is proof that physiotherapy intervention may be useful in diminishing fall rate and near fall incidence among individuals with PD. However, the components of the interventions play a main role in the outcomes. According to the results of these studies, interventions that highly challenge balance are likely to have positive impacts on fall. However, more research is needed to support or refute this finding. Furthermore, the results were also promising in that physiotherapy interventions have a positive impact on fall risk factors. Factors such as balance, functional mobility, FOF, and muscle strength may improve by physiotherapy. However, precisely the best interventions to focus on these factors stay questionable as do the long-term impacts of physiotherapy. One of the limitations in this paper is that most of the included studies barred individuals with other mental and neurological infections. In this manner, the generalizability of the discoveries cannot be accomplished for those with PD and other cognitive impairments or different diseases. Furthermore, this scoping review aims of displaying trends in the literature without giving distinction to methodological quality or empirical "weight" [55]. 


\section{Compliance with ethical standards}

Conflict of interest The authors declare that they have no conflicts of interest.

Ethical approval This article does not contain any studies with human participants or animals performed by any of authors.

Informed consent This paper does not need informed consent.

Open Access This article is licensed under a Creative Commons Attribution 4.0 International License, which permits use, sharing, adaptation, distribution and reproduction in any medium or format, as long as you give appropriate credit to the original author(s) and the source, provide a link to the Creative Commons licence, and indicate if changes were made. The images or other third party material in this article are included in the article's Creative Commons licence, unless indicated otherwise in a credit line to the material. If material is not included in the article's Creative Commons licence and your intended use is not permitted by statutory regulation or exceeds the permitted use, you will need to obtain permission directly from the copyright holder. To view a copy of this licence, visit http://creativecommons.org/licenses/by/4.0/.

\section{References}

1. Wood BH, Bilclough JA, Bowron A, Walker RW (2002) Incidence and prediction of falls in Parkinson's disease: a prospective multidisciplinary study. J Neurol Neurosurg Psychiatry 72(6):721-725

2. Bloem BR, Grimbergen YA, Cramer M, Willemsen M, Zwinderman AH (2001) Prospective assessment of falls in Parkinson's disease. J Neurol 248(11):950-958

3. Stolze H, Klebe S, Zechlin C, Baecker C, Friege L, Deuschl G (2004) Falls in frequent neurological diseases. J Neurol 251(1): 79-84

4. Seymour, K. C., Pickering, R., Rochester, L., Roberts, H. C., Ballinger, C., Hulbert, S. et al. Multicentre, randomised controlled trial of PDSAFE, a physiotherapist-delivered fall prevention programme for people with Parkinson's. J Neurol Neurosurg Psychiatry 2019; 0:1-9.

5. Sherrington C, Whitney JC, Lord SR, Herbert RD, Cumming RG, Close JCT (2008) Effective exercise for the prevention of falls: a systematic review and meta-analysis. J Am Geriatr Soc 56(12): 2234-2243

6. Hely MA, Reid WGJ, Adena MA, Halliday GM, Morris JGL (2008) The Sydney multicenter study of Parkinson's disease: the inevitability of dementia at 20 years. Mov Disord 23(6):837-844

7. Pickering RM, Grimbergen YA, Rigney U, Ashburn A, Mazibrada G, Wood B, Gray P, Kerr G, Bloem BR (2007) A meta-analysis of six prospective studies of falling in Parkinson's disease'. Mov Disord 22(13): 1892-1900

8. Rubinstein TC, Giladi N, Hausdorff JM (2002) The power of cueing to circumvent dopamine deficits: a review of physical therapy treatment of gait disturbances in Parkinson's disease. Mov Disord 17(6):1148-1160

9. Morris ME, Martin CL, Schenkman ML (2010) Striding out with Parkinson disease: evidence-based physical therapy for gait disorders. Phys Ther 90(2):280-288

10. Allen NE, Sherrington C, Paul SS, Canning CG (2011) 'Balance and falls in Parkinson's disease: a meta-analysis of the effect of exercise and motor training. Mov Disord 26(9):1605-1615
11. Shen X, Wong-Yu IS, Mak MK (2016) Effects of exercise on falls, balance, and gait ability in Parkinson's disease: a meta-analysis. Neurorehabil Neural Repair 30(6):512-527

12. Kwakkel G, De Goede CJT, Van Wegen EEH (2007) Impact of physical therapy for Parkinson's disease: a critical review of the literature. Parkinsonism Relat Disord 13(3):478-487

13. Goodwin VA, Richards SH, Taylor RS, Taylor AH, Campbell JL (2008) The effectiveness of exercise interventions for people with Parkinson's disease: a systematic review and meta-analysis. Mov Disord 23(5):631-640

14. Protas EJ, Mitchell K, Williams A, Qureshy H, Caroline K, Lai EC (2005) Gait and step training to reduce falls in Parkinson's disease. Neuro Rehabil 20(3):183-190

15. Thaut M, Rice R, Janzen T, Hurt-Thaut C, McIntosh G (2018) Rhythmic auditory stimulation for reduction of falls in Parkinson's disease: a randomized controlled study. Clin Rehabil 33(1):34-43

16. Sparrow D, DeAngelis TR, Hendron K, Thomas CA, Saint-Hilaire M, Ellis T (2016) (). Highly challenging balance program reduces fall rate in Parkinson disease. J Neurol Phys Ther 40(1):24-30

17. Wong-Yu IS, Mak MK (2015) Task-and context-specific balance training program enhances dynamic balance and functional performance in parkinsonian nonfallers: a randomized controlled trial with six-month follow-up. Arch Phys Med Rehabil 96(12): 2103-2111

18. Shen X, Mak M (2015) Technology-assisted balance and gait training reduces falls in patients with Parkinson's disease: a randomized controlled trail with 12-month follow-up. Neurorehabil Neural Repair 29(2): 103-111

19. Goodwin VA, Richards SH, Henley W, Ewings P, Taylor AH, Campbell JL (2011) An exercise intervention to prevent falls in people with Parkinson's disease: a pragmatic randomised controlled trial. J Neurol Neurosurg Psychiatry 82(11):1232-1240

20. Li F, Harmer P, Fitzgerald K, Eckstrom E, Stock R, Galver J, Maddalozzo G, Batya SS (2012) Tai chi and postural stability in patients with Parkinson's disease'. N Engl J Med 366(6):511-520

21. Ashburn A, Fazakarley L, Ballinger C, Pickering R, Mclellan LD, Fitton C (2007) A randomised controlled trial of a home based exercise programme to reduce the risk of falling among people with Parkinson's disease. J Neurol Neurosurg Psychiatry 78(7):678-684

22. Nieuwboer A, Kwakkel G, Rochester L, Jones D, Van Wegen E, Willems AM, Chavret F, Hetherington V, Baker K, Lim I (2007) Cueing training in the home improves gait-related mobility in Parkinson's disease: the RESCUE trial'. J Neurol Neurosurg Psychiatry 78(2):134-140

23. Canning CG, Lord S, Heritier S, Heller G, Howard K, Allen N, Latt M, Murray S, O’Rourke S, Paul S, Song J, Fung V (2015) Exercise for falls prevention in Parkinson disease: a randomized controlled trial. Am Acad Neurol 84(4):304-312

24. Morris M, Menz H, McGinley J, Watts JJ, Watts J, Huxham F, Murphy A, Danoudis M, Iansek R (2015) A randomized controlled trial to reduce falls in people with Parkinson's disease. Neurorehabil Neural Repair 29(8):777-785

25. Martin T, Weatherall M, Anderson T, MacAskill M (2015) A randomized controlled feasibility trial of a specific cueing program for falls management in persons with Parkinson disease and freezing of gait. J Neurol Phys Ther 39(3):179-184

26. Smania N, Corato E, Tinazzi M, Stanzani C, Fiaschi A, Girardi P, Gandolfi M (2010) Effect of balance training on postural instability in patients with idiopathic Parkinson's disease. Neurorehabil Neural Repair 24(9):826-860

27. Gao Q, Leung A, Yang Y, Wei Q, Guan M, Jia C, He C (2014) Effect of Tai Chi on balance and fall prevention in Parkinson's disease: a randomized controlled trial. Clin Rehabil 28(8):748-753

28. Silva-Batista C, Corcos DM, Kanegusuku H, Piemonte MEP, Gobbi LTB, de Lima-Pardini AC, de Mello MT, Forjaz CLM, 
Ugrinowitsch C (2018) Balance and fear of falling in subjects with Parkinson's disease is improved after exercises with motor complexity. Gait Posture 61:90-97

29. Wong-Yu IS, Mak MK (2015b) Multi-dimensional balance training programme improves balance and gait performance in people with Parkinson's disease: a pragmatic randomized controlled trial with 12-month follow-up. Parkinsonism Relat Disord 21(6):615-621

30. Muller V, Mohr B, Rosin R, Pulvermuller F, Muller F, Birbaumer N (1997) Short-term effects of behavioral treatment on movement initiation and postural control in Parkinson's disease: a controlled clinical study. Mov Disord 12(3):306-320

31. Hirsch MA, Toole T, Maitland CG, Rider RA (2003) The effects of balance training and high-intensity resistance training on persons with idiopathic Parkinson's disease. Arch Phys Med Rehabil 84(4): $1109-1117$

32. Schmitz-Hubsch T, Pyfer D, Kielwein K, Fimmers R, Klockgether T, Wullner U (2006) Qigong exercise for the symptoms of Parkinson's disease: a randomized, controlled pilot study. Mov Disord 21(4):543-548

33. Cakit BD, Saracoglu M, Genc H, Erdem HR, Inan L (2007) The effects of incremental speed-dependent treadmill training on postural instability and fear of falling in Parkinson's disease. Clin Rehabil 21(8):698-705

34. Hackney ME, Earhart GM (2008) () 'Tai Chi improves balance and mobility in people with Parkinson disease'. Gait Posture 28(3):456-460

35. Hackney ME, Kantorovich S, Levin R, Earhart GM (2007) Effects of tango on functional mobility in Parkinson's disease: a preliminary study. J Neurol Phys Ther 31(14):173-179

36. Morris ME, Iansek R, Kirkwood B (2009) A randomized controlled trial of movement strategies compared with exercise for people with Parkinson's disease. Mov Disord 24(1):64-71

37. Kurtais Y, Kutlay S, Tur B, Gok H, Akbostanci C (2008) Does treadmill training improve lower-extremity tasks in Parkinson disease? A randomized controlled trial. Clin J Sport Med 18(3):289291

38. Ebersbach G, Ebersbach A, Edler D, Kaufhold O, Kusch M, Kupsch A, Wissel J (2010) Comparing exercise in Parkinson's disease - the Berlin BIG Study. Mov Disord 25(12):1902-1908

39. Yen CY, Lin KH, Hu MH, Wu RM, Lu TW, Lin CH (2011) Effects of virtual reality-augmented balance training on sensory organization and attentional demand for postural control in people with Parkinson disease: a randomized controlled trial. Phys Ther 91(6): 862-874

40. Duncan RP, Earhart GM (2012) Randomized controlled trial of community-based dancing to modify disease progression in Parkinson disease'. Neurorehabil Neural Repair 26(2):132-143

41. Stack E, Roberts H, Ashburn A (2012) The PIT: SToPP trial-a feasibility randomised controlled trial of home-based physiotherapy for people with Parkinson's disease using video-based measures to preserve assessor blinding. Parkinsons Dis 2012:36023

42. Conradsson D, Lofgren N, Nero H, Hagstromer M, Stahle A, Lokk J, Franzen E (2015) The effects of highly challenging balance training in elderly with Parkinson's disease: a randomized controlled trial. Neurorehabil Neural Repair 29(9):827-836

43. Volpe D, Giantin M, Maestri R, Frazzitta G (2014) Comparing the effects of hydrotherapy and land-based therapy on balance in patients with Parkinson's disease: a randomized controlled pilot study. Clin Rehabil 28(2):210-217

44. Allen NE, Canning CG, Sherrington C, Lord SR, Latt MD, Close JC, O'rourke SD, Murray SM, Fung VS (2010) The effects of an exercise program on fall risk factors in people with Parkinson's disease: a randomized controlled trial. Mov Disord 25(9):12171225

45. Mak MK, Hui-Chan CW (2008) Cued task-specific training is better than exercise in improving sit-to-stand in patients with Parkinson's disease: a randomized controlled trial. Mov Disord 23(4):501-509

46. Sage MD, Almeida QJ (2009) Symptom and gait changes after sensory attention focused exercise vs aerobic training in Parkinson's disease. Mov Disord 24(8):1132-1138

47. Pohl M, Rockstroh G, Ruckriem S, Mrass G, Mehrholz J (2003) Immediate effects of speed-dependent treadmill training on gait parameters in early Parkinson's disease. Arch Phys Med Rehabil 84(12):1760-1766

48. Frazzitta G, Maestri R, Uccellini D, Bertotti G, Abelli P (2009) Rehabilitation treatment of gait in patients with Parkinson's disease with freezing: a comparison between two physical therapy protocols using visual and auditory cues with or without treadmill training. Mov Disord 24(8):1139-1143

49. Hackney M, Earhart G (2009) Effects of dance on movement control in Parkinson's disease: a comparison of argentine tang and American ballroom. J Rehabil Med 41:475-481

50. Chaiwanichsiri D, Wangno W, Kitisomprayoonkul W, Bhidayasiri R (2011) Treadmill training with music: a new approach for Parkinson's gait facilitation'. Asian Biomed 5(5):649-654

51. Reuter I, Mehnert S, Leone P, Kaps M, Oechsner M, Engelhardt M (2011) Effects of a flexibility and relaxation programme, walking, and nordic walking on Parkinson's disease. J Aging Res:232-247

52. Perry L, Kendrick D, Morris R, Dinan S, Masud T, Skelton D, Iliffe S, Team FTPS (2012) Completion and return of fall diaries varies with participants' Level of education, first language, and baseline fall risk. J Gerontol Ser A Biol Med Sci 67(2):210-214

53. Addison O, Dibble LE, Papa E (2009) The effects of exercise on balance in persons with Parkinson's disease: a systematic review across the disability spectrum. J Neurol Phys Ther 33(1):14-26

54. Zijlstra GA, Van Haastregt JC, Van Rossum E, Van Eijk JT, Yardley L, Kempen GI (2007) Interventions to reduce fear of falling in community-living older people: a systematic review. J Am Geriatr Soc 55(4):603-615

55. Arksey H, O’Malley L (2005) Scoping studies: towards a methodological framework. Int J Soc Res Methodol 8(1):19-32

Publisher's note Springer Nature remains neutral with regard to jurisdictional claims in published maps and institutional affiliations. 